\title{
Trace Elements in Apatite as Genetic Indicators of the Evate Apatite-Magnetite Deposit, NE Mozambique
}

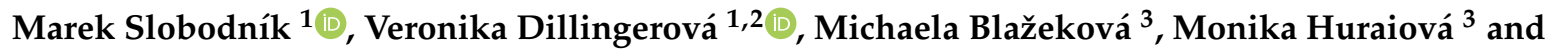 \\ Vratislav Hurai ${ }^{4, *}$ (D) \\ 1 Department of Geological Sciences, Masaryk University, 61137 Brno, Czech Republic; \\ marek@sci.muni.cz (M.S.); 380348@mail.muni.cz (V.D.) \\ 2 Department of Chemistry, Masaryk University, 61137 Brno, Czech Republic \\ 3 Department of Mineralogy and Petrology, Comenius University, 84215 Bratislava, Slovakia; \\ misa.gajdos@gmail.com (M.B.); monika.huraiova@uniba.sk (M.H.) \\ 4 Earth Science Institute, Slovak Academy of Sciences, 84005 Bratislava, Slovakia \\ * Correspondence: vratislav.hurai@savba.sk; Tel.: +421-2-32293209
}

Received: 4 November 2020; Accepted: 10 December 2020; Published: 14 December 2020

check for updates

\begin{abstract}
The Evate deposit is a Neoproterozoic ( $\sim 590 \mathrm{Ma})$ magnetite-apatite-carbonate body emplaced parallel to foliation of the Monapo granulite complex in NE Mozambique. A complicated history of the deposit is recorded in apatite textures visualized in cathodoluminescence (CL) images. In spite of different solid and fluid inclusions, mineral assemblages, and the CL textures, electron probe microanalyses indicate relatively consistent apatite compositions corresponding to fluorapatite $\left(X_{\mathrm{F}}=0.51-0.73, X_{\mathrm{OH}}=0.21-0.47, X_{\mathrm{Cl}}=0.02-0.06\right)$ with limited belovite- and cesanite-type substitutions. Laser ablation inductively coupled plasma mass spectrometric analyses show that apatites from unaltered magnetite-forsterite-spinel ores are depleted in Y, REE, Ba, and Sr compared to apatites from carbonate-anhydrite ores. Hydrothermally overprinted apatites with complex patchy domain CL textures are enriched in Y-REE in greenish-grey zones, Fe-U-Th in blue zones, and Mn-Sr-Ba in brown domains. Observed CL-emissions in the Evate apatites result from very subtle variations in REE, $\mathrm{Mn}$, and $\mathrm{U}$ contents controlled by the variability of redox conditions. The decreased Th:U ratio in the hydrothermally overprinted apatites reflects the oxidation and partial removal of $\mathrm{U}^{4+}$ from the apatite structure during the interaction with oxidizing aqueous fluids capable of transporting $\mathrm{U}^{6+}$. Flat, LREE (La-Sm)-enriched chondrite-normalized patterns with $\mathrm{Eu} / \mathrm{Eu}^{*}=0.7-1.4$ and $\mathrm{Ce} / \mathrm{Ce}^{*}=0.9-1.5$, together with concentrations of diagnostic trace elements (Sr, Mn, Y, REE) are consistent with apatites from magmatic carbonatites and phoscorites. This study corroborates that the Evate deposit is a post-collisional orogenic carbonatite genetically linked with mafic plutonic rocks intruding the Monapo granulite complex after granulite-facies metamorphism, and later overprinted by intensive hydrothermalism. The Evate apatite is peculiar in retaining its pristine magmatic signature despite the extensive hydrothermal-metasomatic alteration accompanied by dissolution-reprecipitation.
\end{abstract}

Keywords: apatite; carbonatite; cathodoluminescence; geochemistry; Evate; Mozambique

\section{Introduction}

The Evate deposit in NE Mozambique is the largest undeveloped apatite deposit in southeast Africa. The genesis of the deposit is not precisely known and includes magmatic, magmatic-hydrothermal, and hydrothermal-metasomatic models. For instance, the deposit was interpreted as a differentiated nelsonite-carbonatite sill intruding granulite-facies rocks of the Neoproterozoic Monapo Complex [1]. The intrusive magmatic origin and close genetic relationship with 
neighboring felsic and mafic plutons is supported by fenite aureoles around apatite-magnetite-carbonate bodies [2]. The hydrothermal-metasomatic origin was deduced from the preferential accumulation of the apatite along fractures [3], and the presence of apparently primary aqueous fluid inclusions in apatite [4]. The deposit was also designated as metasomatized or metamorphosed marble $[2,5,6]$, implying a skarn-like origin linked with a felsic-to-intermediate magmatism. The Evate could also be affiliated with the magnetite-group Kiruna-type iron oxide-apatite (IOA) deposits such as those in the Chilean Iron Belt [7] or Mongolia [8]. However, this link does not seem to be well-supported by increased $\mathrm{Ti}$ and $\mathrm{Mg}$ contents in the Fe-oxide assemblage [9]. Possible genetic relationship with continental rift-bound carbonatites [10-12] is invalidated by the age of magnetite-spinel-olivine-apatite ores coeval with the retrograde stage of the Neoproterozoic granulite-facies metamorphism [13]. Hence, the formation within an extension zone of a collapsed orogen [14] is plausible. Moreover, the Late Cambrian-to-Late Ordovician zirconolite, monazite, and uranothorite indicate an extensive hydrothermal-metasomatic overprint coincidental with the Early Palaeozoic rifting $[9,15]$.

Apatite is an important indicator of magmatic and hydrothermal evolution owing to its capability of accommodating a plethora of elements. The rapidly growing amount of information indicates the wide variability in apatite chemistry and its sensitivity to growth conditions and processes to which the apatite was exposed. Recently, apatite appears a suitable petrogenetic and geochemical indicator in an effort to develop criteria for distinguishing magmatic and hydrothermal origins of apatite-bearing ore deposits [16] based on trend analysis supported by ion compatibility and structural/crystallochemical characteristics of the apatite [17-19]. For these studies, apatite is a suitable candidate because it crystallizes during the fractionation of carbonatite and silicate melts due to low solubility of phosphorus and limited substitution in major rock-forming minerals [20-23]. Lanthanides in various genetic types of apatite are employed in deciphering the evolution of parental magmas and the degree of the melt fractionation [24]. Discriminant analysis of trace elements provides a useful tool for the identification of the apatite source rocks [25] and genetic types of apatite-bearing ore deposits [26-28]. Normalized rare earth element distribution patterns serve as indicators of the oxidation state and $\mathrm{pH}$ of ore-forming fluids $[29,30]$.

Here we report on in situ laser ablation inductively coupled plasma mass spectrometric (LA-ICPMS) and electron probe micro-analytical (EPMA) study of apatites from the Evate deposit. Hot cathodoluminescence imaging (CL) was employed to characterize the internal texture of investigated apatite grains in order to discriminate primary growth textures from those associated with superimposed hydrothermal metasomatic alterations. The study was conducted with the aim of obtaining additional geochemical evidence for the still poorly constrained origin of the Evate deposit.

\section{Geological Background}

The Evate deposit is located on the SE flank of the Monapo Complex (Figure 1)-an oval structure, $40 \times 35 \mathrm{~km}$ in size, interpreted as a relic of a Neoproterozoic nappe metamorphosed in granulite-facies conditions [31-34] thrusted over the Mesoproterozoic basement metamorphosed in amphibolite-facies conditions [35,36]. The deposit has a strike length of about $1.8 \mathrm{~km}$ and a thickness of $\sim 600 \mathrm{~m}$ in the central portion [1] and contains at least $155 \mathrm{Mt}$ of apatite ore grading $9.3 \mathrm{wt}$. $\% \mathrm{P}_{2} \mathrm{O}_{5}$ down to $-100 \mathrm{~m}$ level [3].

The age of Evate is well-defined by the U-Pb-(Th) radiometric dating $[9,13,15,37]$. The oldest age record, $590 \mathrm{Ma}$, has been obtained from zircon and baddeleyite in magnetite-apatite-olivine-spinel ores, and from monazite in fenite. $\mathrm{Nb}$-poor zirconolite and monazite-(Ce) returned an Upper Ordovician age (443 \pm 3 and $449 \pm 2 \mathrm{Ma}$ ) interpreted as a metamorphic-hydrothermal overprint. An Upper Cambrian age of $\mathrm{Nb}$-rich zirconolite (485 $\pm 9 \mathrm{Ma})$ and uranothorianite $(493 \pm 10 \mathrm{Ma})$ projected between the monazite-(Ce) age of the albite-pyrite-monazite assemblage in anhydrite-bearing carbonatite and that of zircon and baddeleyite from magnetite-apatite-olivine-spinel ores. Mineral-forming processes in the Evate deposit ended with the precipitation of zeolites from low-temperature $\left(<300^{\circ} \mathrm{C}\right)$ alkaline carbo-hydrothermal fluids [9]. 


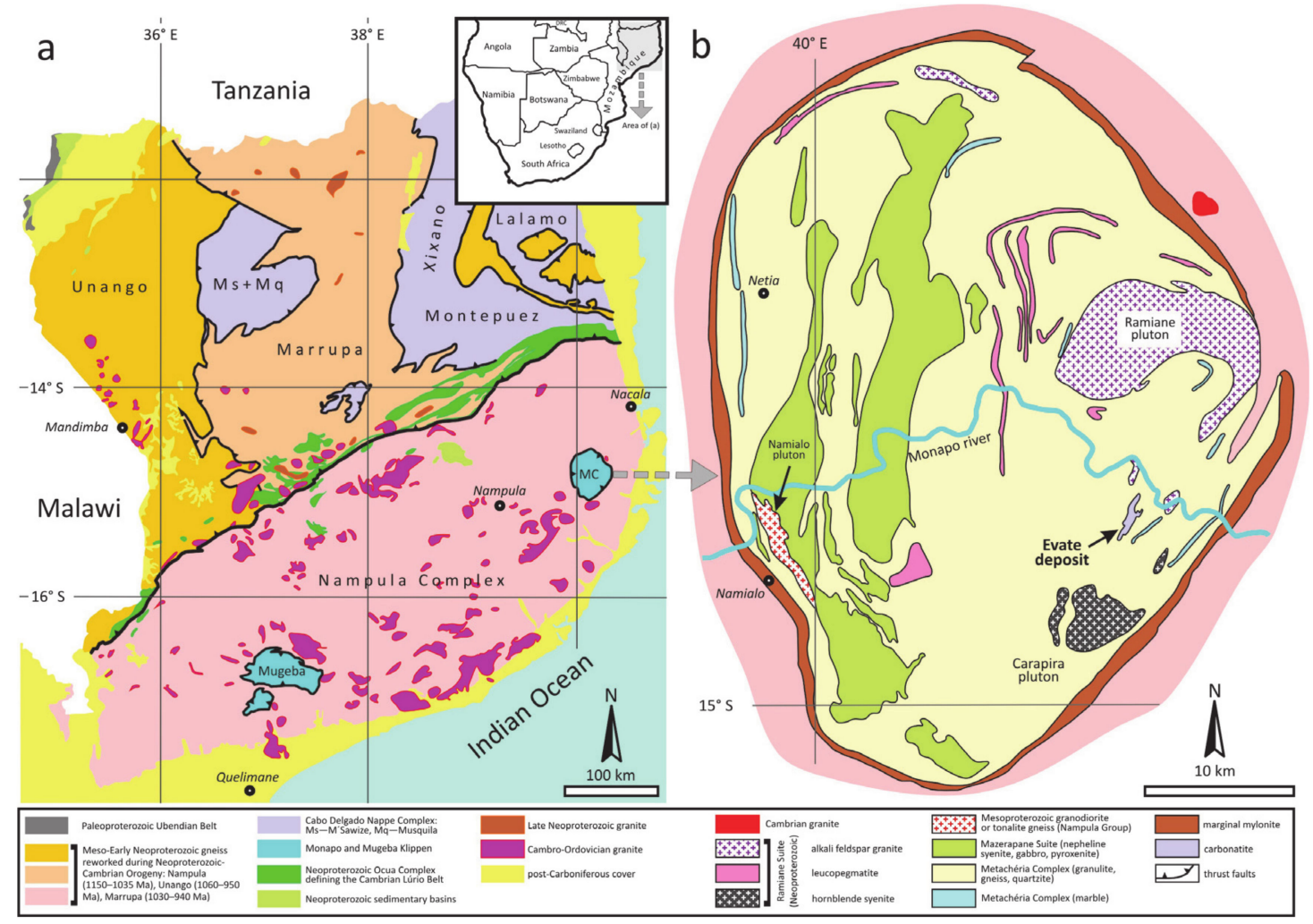

Figure 1. Simplified geological maps of the north-eastern Mozambique (a) and the Monapo Complex (MC) with the Evate apatite-magnetite deposit indicated by arrow (b). Adapted from [2].

The surrounding Monapo Complex is composed of variegated, strongly deformed granulites and gneisses intruded by weakly deformed, silica-oversaturated alkaline felsic and silica-undersaturated, alkaline mafic- to ultramafic igneous rocks [2]. The alkaline rocks form steeply dipping, concentric lithologies, suggesting multiple cone sheet intrusions and magmatic segregation from fractional crystallization [38]. The magmatic layering parallel to the foliation of the gneissic country rocks suggests the carbonatite intrusion into a tectonically active environment and multiple subsequent tectonic deformations [1].

SHRIMP U-Pb zircon data obtained from the alkaline felsic pluton and the surrounding granulite/gneiss returned ages of 618-646 Ma and 626-642 Ma, respectively [5,39], suggesting the intrusion synchronous with the granulite-facies metamorphism. The U-Pb zircon data have later been reinterpreted as those reflecting the age of granulite-facies metamorphism [2].

The age of the mafic-ultramafic magmatic suite remains unknown. The absence of a contact aureole with surrounding granulites has been interpreted as evidence of the intrusion during peak-temperature metamorphic conditions. Exhumation and hydration at 568-601 Ma have been deduced from U-Pb ages of zircon margins in the granulites and the felsic pluton [2,33]. The age of the latest tectonic deformations within the Monapo Complex at 550-568 Ma has been indirectly inferred from an undeformed aplite vein [39], although the local, 550 Ma old deformation fabrics have been suggested to record the collision between northern and southern Gondwana starting at 590 Ma [33].

The thermal history of the Monapo Complex involves granulite-facies metamorphism at $\sim 900{ }^{\circ} \mathrm{C}$ and $>10 \mathrm{kbar}$ followed by isobaric cooling, exhumation, and hydration at $550-700{ }^{\circ} \mathrm{C}$ and $\sim 4-7 \mathrm{kbar}$ [33]. The metamorphism is attributed to crustal thickening related to overriding the Cabo Delgado Nappe Complex and shortening along the Lurio Belt [40]. The fenitization around Evate carbonatite occurred at $\sim 500{ }^{\circ} \mathrm{C}$ and $2-5 \mathrm{kbar}$ and was coincidental with the retrogression in amphibolite-facies conditions [37]. After the Neoproterozoic-Cambrian orogenesis, the Monapo Complex underwent high-temperature, low-pressure metamorphism accompanied by the migmatization and intrusions of post-orogenic 
granites dated between 538 and $470 \mathrm{Ma}[6,32,35]$. The granite generation and the high-T metamorphism have been attributed to lithosphere delamination and asthenosphere uprise following the collapse of East-African orogen $[6,41]$.

\section{Methods}

Chemical composition of apatite and associated minerals was determined using a CAMECA SX-100 electron probe micro-analyzer (EPMA) in the State Geological Institute in Bratislava, Slovakia, operated in wavelength dispersive mode (WDS) with the following analytical conditions: $15 \mathrm{kV}$ accelerating voltage, $40 \mathrm{nA}$ (Y, REE, U, Th, Pb) and $20 \mathrm{nA}$ (other elements) beam current, and beam diameter focused to $2-5 \mu \mathrm{m}$. The following excitation lines, crystals, and calibration standards were employed: F-K $\alpha$, LPC0, $\mathrm{CaF}_{2} ; \mathrm{Cl}-\mathrm{K} \alpha$, LPET, NaCl; Th-M $\alpha$, LPET, ThO 2 ; U-M $\beta, \mathrm{LPET}, \mathrm{UO}_{2} ; \mathrm{Pb}-\mathrm{M} \alpha$, LPET; Si-K $\alpha$, TAP, As-L $\alpha$, TAP; wollastonite; Ca-K $\alpha$, LPET, apatite; Ti-K $\alpha, \mathrm{LLIF}, \mathrm{TiO}_{2} ; \mathrm{Na}-\mathrm{K} \alpha, \mathrm{TAP}$, albite; Mn-K $\alpha$, LLIF, rhodonite; P-K $\alpha$, LPET, apatite; S-K $\alpha$, LPET, barite; Fe-K $\alpha$, LLIF, fayalite; Sr-L $\alpha$, LPET, $\mathrm{SrTiO}_{3} ; \mathrm{Y}-\mathrm{L} \alpha, \mathrm{LPET}_{\text {, YPO }} ; \mathrm{La}-\mathrm{L} \alpha, \mathrm{LLIF}, \mathrm{LaPO}_{4} ; \mathrm{Ce}-\mathrm{K} \alpha$, LLIF, CePO $;$ Pr-L $\beta, \mathrm{LLIF}, \mathrm{PrPO}_{4} ; \mathrm{Nd}-\mathrm{L} \alpha$, LLIF, $\mathrm{NdPO}_{4} ; \mathrm{Sm}-\mathrm{L} \alpha, \mathrm{LLIF}, \mathrm{SmPO}_{4} ; \mathrm{Eu}-\mathrm{L} \beta, \mathrm{LLIF}, \mathrm{EuPO}_{4} ; \mathrm{Gd}-\mathrm{L} \alpha, \mathrm{LLIF}, \mathrm{GdPO}_{4} ; \mathrm{Tb}-\mathrm{L} \alpha, \mathrm{LLIF}_{1}$ TbPO ; Dy-L $\beta$, LLIF, DyPO $;$ Ho-L $\beta$, LLIF, $\mathrm{HoPO}_{4} ; \mathrm{Er}-\mathrm{L} \beta, \mathrm{LLIF}, \mathrm{ErPO}_{4} ; \mathrm{Tm}-\mathrm{L} \alpha, \mathrm{LLIF}, \mathrm{TmPO} ; \mathrm{Yb}-\mathrm{L} \alpha, \mathrm{LLIF}$, $\mathrm{YbPO}_{4} ; \mathrm{Lu}-\mathrm{L} \beta, \mathrm{LLIF}, \mathrm{LuPO}_{4}$.

Thin sections with apatite grains were examined using back-scatter electron imaging (BSE) prior to analysis. Matrix effects were resolved using the $X-\varphi$ correction method [42]. EPMA chemical data were recalculated on the basis of 26 total anions: $(\mathrm{F}+\mathrm{Cl}+\mathrm{OH})=2$ and $24 \mathrm{O}$. The final crystallochemical formula was obtained after normalization to a total of 10 cations in position $A$, according to the general formula: $A_{10}\left(\mathrm{TO}_{4}\right)_{6}(\mathrm{OH}, \mathrm{F}, \mathrm{Cl})_{2}$ [43]. The $\mathrm{OH}$ content was calculated assuming the presence of $\mathrm{F}$ and $\mathrm{Cl}$ only. Carbon content was derived from the equation: $\mathrm{C}=6-(\mathrm{P}+\mathrm{Si}+\mathrm{S}+\mathrm{As})[21]$. A tetrahedral substitution index $T S I=100(\mathrm{Si}+\mathrm{S}+\mathrm{C}) / \mathrm{P}$ [16] was calculated from the crystallochemical formula to characterize the degree of substitution in the position $T$. In a similar way, the index $C S I=100(10-\mathrm{Ca}) / \mathrm{Ca}[44]$ indicates the degree of Ca substitution by other cations with charges $1^{+}$to $3^{+}$. Ellestadite- $\left(\mathrm{Si}^{4+}+\mathrm{S}^{6+}=2 \mathrm{P}^{5+}\right.$ in the $T$ position) and britholite-type substitutions $\left(\mathrm{REE}^{3+}+\mathrm{Si}^{4+}=\mathrm{Ca}^{2+}+\mathrm{P}^{5+}\right.$ in the Ca-polyhedral position) are defined by the mutual correlations of CSI and TSI indices.

Hot cathodoluminescence (CL) observations were conducted in the Institute of Geochemistry, Mineralogy and Mineral Resources (Faculty of Science, Charles University in Prague, Czech Republic) using an Olympus microscope equipped with a hot cathode HC6-LM (Lumic, Germany) discharge that provided the energy of $14 \mathrm{keV}$ and beam current up to $0.01 \mathrm{~mA}$. CL images were captured using an adapted digital video-camera.

CL-emission spectra were obtained using a Peltier-cooled Avantes SensLine AvaSpec-ULS2048LTEC-USB2 (Avantes, Apeldoorn, The Netherlands) spectrometer with a 2048 pixel CCD detector. Resolution $0.27 \mathrm{~nm}$ per pixel was obtained by using a $100 \mu \mathrm{m}$ slit, and diffraction grating of $600 \mathrm{lines} / \mathrm{mm}$.

Apatite grains were analyzed using in situ laser ablation inductively coupled plasma mass spectrometry (LA-ICPMS) at the Department of Chemistry of the Masaryk University in Brno, Czech Republic. The analyses involved the ablation of craters, $110 \mu \mathrm{m}$ in diameter, drilled with a Photon Machines Excite (Teledyne Cetac Technologies, Omaha, NE, USA) excimer laser system operating at a wavelength of $193 \mathrm{~nm}$ with a repetition rate of $10 \mathrm{~Hz}$ and laser energy of $2.5 \mathrm{~mJ} / \mathrm{pulse}$. The ablated material was carried by helium and mixed with nitrogen and argon before injection into the plasma source of a Thermo Scientific ${ }^{\mathrm{TM}}$ Element 2 (Thermo Fisher Scientific, Waltham, MA, USA, and Bremen, Germany) ICP-MS. Each analysis lasted $60 \mathrm{~s}$ after measuring the gas blank for $60 \mathrm{~s}$. The following elements were analyzed: ${ }^{44} \mathrm{Ca},{ }^{55} \mathrm{Mn},{ }^{56} \mathrm{Fe},{ }^{88} \mathrm{Sr},{ }^{89} \mathrm{Y},{ }^{137} \mathrm{Ba},{ }^{139} \mathrm{La},{ }^{140} \mathrm{Ce}$, ${ }^{141} \mathrm{Pr},{ }^{146} \mathrm{Nd},{ }^{147} \mathrm{Sm},{ }^{153} \mathrm{Eu},{ }^{157} \mathrm{Gd},{ }^{159} \mathrm{~Tb},{ }^{163} \mathrm{Dy},{ }^{165} \mathrm{Ho},{ }^{166} \mathrm{Er},{ }^{169} \mathrm{Tm},{ }^{172} \mathrm{Yb},{ }^{175} \mathrm{Lu},{ }^{208} \mathrm{~Pb},{ }^{232} \mathrm{Th},{ }^{238} \mathrm{U}$. Each grain was measured by a total of 5 ablation spots. Limits of detection (ppm) were as follows: ${ }^{44} \mathrm{Ca}-2.0-293,{ }^{55} \mathrm{Mn}-0.04-0.30,{ }^{56} \mathrm{Fe}-0.03-0.41,{ }^{88} \mathrm{Sr}-0.003-1.65,{ }^{89} \mathrm{Y}-0.003-0.413,{ }^{137} \mathrm{Ba}-0.011-1.1$, ${ }^{139} \mathrm{La}-0.001-0.049,{ }^{140} \mathrm{Ce}-0.001-0.033,{ }^{141} \mathrm{Pr}-0.001-0.029,{ }^{146} \mathrm{Nd}-0.003-0.233,{ }^{147} \mathrm{Sm}-0.001-0.171$, 
${ }^{153} \mathrm{Eu}-0.001-0.04,{ }^{157} \mathrm{Gd}-0.003-0.411,{ }^{159} \mathrm{~Tb}-0.001-0.041,{ }^{163} \mathrm{Dy}-0.002-0.081,{ }^{165} \mathrm{Ho}-0.001-0.008$, ${ }^{166} \mathrm{Er}-0.001-0.024,{ }^{169} \mathrm{Tm}-0.001-0.009,{ }^{172} \mathrm{Yb}-0.001-0.107,{ }^{175} \mathrm{Lu}-0.001-0.029,{ }^{208} \mathrm{~Pb}-0.01-0.015$, ${ }^{232} \mathrm{Th}-0.001-0.004,{ }^{238} \mathrm{U}-0.001-0.005$.

Elemental maps were analyzed using a quadrupole Agilent 7900 (Agilent Technologies Inc., Santa Clara, CA, USA). ICP-MS spectrometer equipped with a collision-reaction cell (CRC) for suppressing possible polyatomic interferences. Elemental imaging was performed using the line scan mode applied to a selected area. The following 17 elements were analyzed: ${ }^{23} \mathrm{Na},{ }^{24} \mathrm{Mg},{ }^{31} \mathrm{P}{ }^{44} \mathrm{Ca}$, ${ }^{55} \mathrm{Mn},{ }^{88} \mathrm{Sr},{ }^{137} \mathrm{Ba},{ }^{139} \mathrm{La},{ }^{140} \mathrm{Ce},{ }^{141} \mathrm{Pr},{ }^{146} \mathrm{Nd},{ }^{153} \mathrm{Eu},{ }^{157} \mathrm{Gd},{ }^{163} \mathrm{Dy},{ }^{165} \mathrm{Ho},{ }^{166} \mathrm{Er}$. Limits of detection (ppm) were as follows: ${ }^{23} \mathrm{Na}-752,{ }^{24} \mathrm{Mg}-29,{ }^{31} \mathrm{P}-451,{ }^{44} \mathrm{Ca}-1351,{ }^{55} \mathrm{Mn}-4.7,{ }^{88} \mathrm{Sr}-0.01,{ }^{137} \mathrm{Ba}-0.01$, ${ }^{139} \mathrm{La}-0.43,{ }^{140} \mathrm{Ce}-0.01,{ }^{141} \mathrm{Pr}-0.61,{ }^{146} \mathrm{Nd}-1.8,{ }^{153} \mathrm{Eu}-0.3,{ }^{157} \mathrm{Gd}-0.59,{ }^{163} \mathrm{Dy}-0.34,{ }^{165} \mathrm{Ho}-0.13$, ${ }^{166} \mathrm{Er}-0.19$. The analyzed surface was scanned with a laser beam along a straight line with a constant scan rate of $33 \mu \mathrm{m} / \mathrm{s}$, beam fluence of $7 \mathrm{~J} / \mathrm{cm}^{2}$, and repetition rate of $10 \mathrm{~Hz}$. The laser beam diameter and the distance between individual lines were both $50 \mu \mathrm{m}$.

Glass standard NIST 610 was used for quantification of elemental concentration. NIST 612 and NIST 614 glass standards were measured as control samples. The average concentration of Ca determined by EPMA was used for the internal standard correction. Data reduction was carried out using a custom-made Python program developed at the Department of Chemistry of the Masaryk University. The software permits automatic peak selection using timestamps from laser to select ablation peaks and background. The selected spots were visualized in interactive graphs. Interfered spots with signals outside homogeneous distribution levels were discarded. The software contains multiple steps for data reduction (spot and background selection, background correction, quantification using standard measurements, internal standard correction, and total sum correction), which can be exported as Excel tables.

\section{Samples}

Apatite is the most abundant phosphate in Evate ores. Forsterite- and magnetite-rich parts of carbonate bodies contain large isolated apatite crystals embedded in carbonate matrix or intergrown with forsterite, magnetite, ilmenite, pyrrhotite, calcite-dolomite, amphibole, phlogopite, zircon, and baddeleyite (Figure 2a,b). Forsterite is often serpentinized along cracks and replaced by phlogopite and amphibole along grain margins. Magnetite contains geikielite exsolution lamellae decorated by Zn-rich spinel, which also creates isolated inclusions within magnetite, clusters along boundaries with apatite, baddeleyite, and ilmenite, as well as massive crystal aggregates.

Coarse-grained, light-green apatite also occurs in pink-to-white carbonate matrix devoid of Fe-Mg oxides (Figure 2c). The apatite is here associated with barian phlogopite, amphibole, K-Ba-feldspar, anhydrite, celestine, barite, and occasional scapolite and cerianite. Sr-rich anhydrite/gypsum (up to $1.7 \mathrm{wt}$. \% SrO) occurs in all rock-types, yet less frequently in the forsterite-magnetite ores. The ores dominated by the carbonate-apatite-anhydrite assemblage are hereafter named carbonatite, whereas those dominated by the magnetite-spinel-forsterite assemblage are designated as nelsonite. The subdivision in nelsonite and carbonatite is, however, rather ambiguous and continuous transitions do exist between both rock types. Apatite-bearing drill cores illustrated in Figure 2 have been selected for the LA-ICPMS study as representatives of forsterite-free carbonatite (EVT6) and forsterite-spinel nelsonite, the latter subdivided into the fresh nelsonite with almost intact olivines (EVT2) and the altered nelsonite with strongly serpentinized olivines locally replaced by amphiboles and phlogopite (EVT8).

The subdivision to nelsonite and carbonatite is also justified by different types of mineral and fluid inclusions [9]. Apatites from forsterite-magnetite rocks contain primary $\mathrm{N}_{2}, \mathrm{~N}_{2}-\mathrm{CO}_{2}, \mathrm{~N}_{2}$-carbonate, and brine-carbonate inclusions (Figure $3 \mathrm{a}, \mathrm{e}$ ), and ubiquitous inclusions of edenite or pyrrhotite oriented parallel with the host apatite crystallographic c-axis (Figure 3a-c). In contrast, the apatite from carbonatites is typical of a great abundance of fluid and gas inclusions (Figure $3 \mathrm{~d}-\mathrm{g}$ ) accompanied by mineral inclusions of anhydrite and crystals of the $\mathrm{BaSO}_{4}-\mathrm{SrSO}_{4}$ solid-solution series. The majority 
of rounded inclusions are empty vacuoles, and the others are filled with aqueous fluid with a variable volume of $\mathrm{CO}_{2}$-rich gas. An aqueous liquid phase occasionally contains halite and hematite daughter crystals.

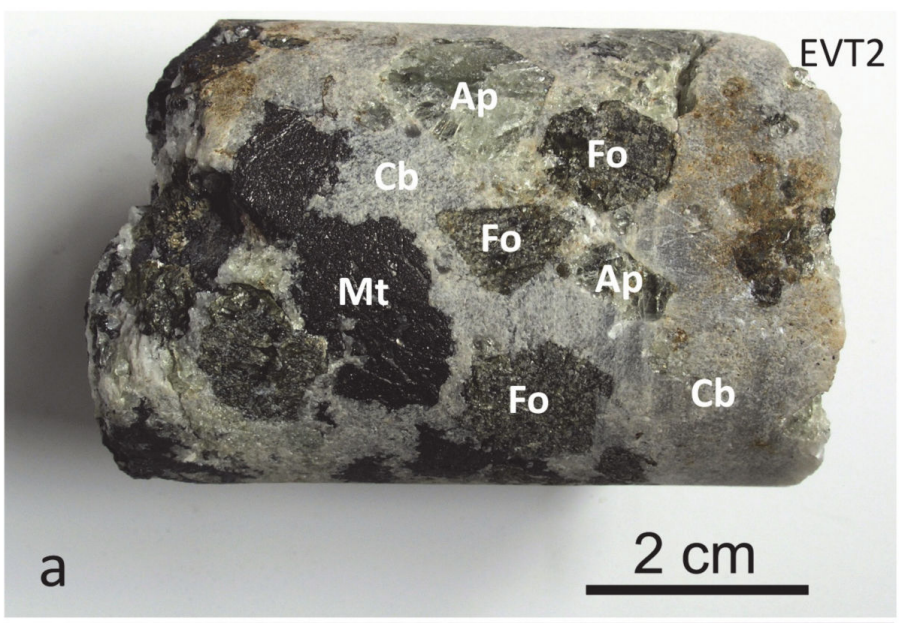

\section{EVT8}
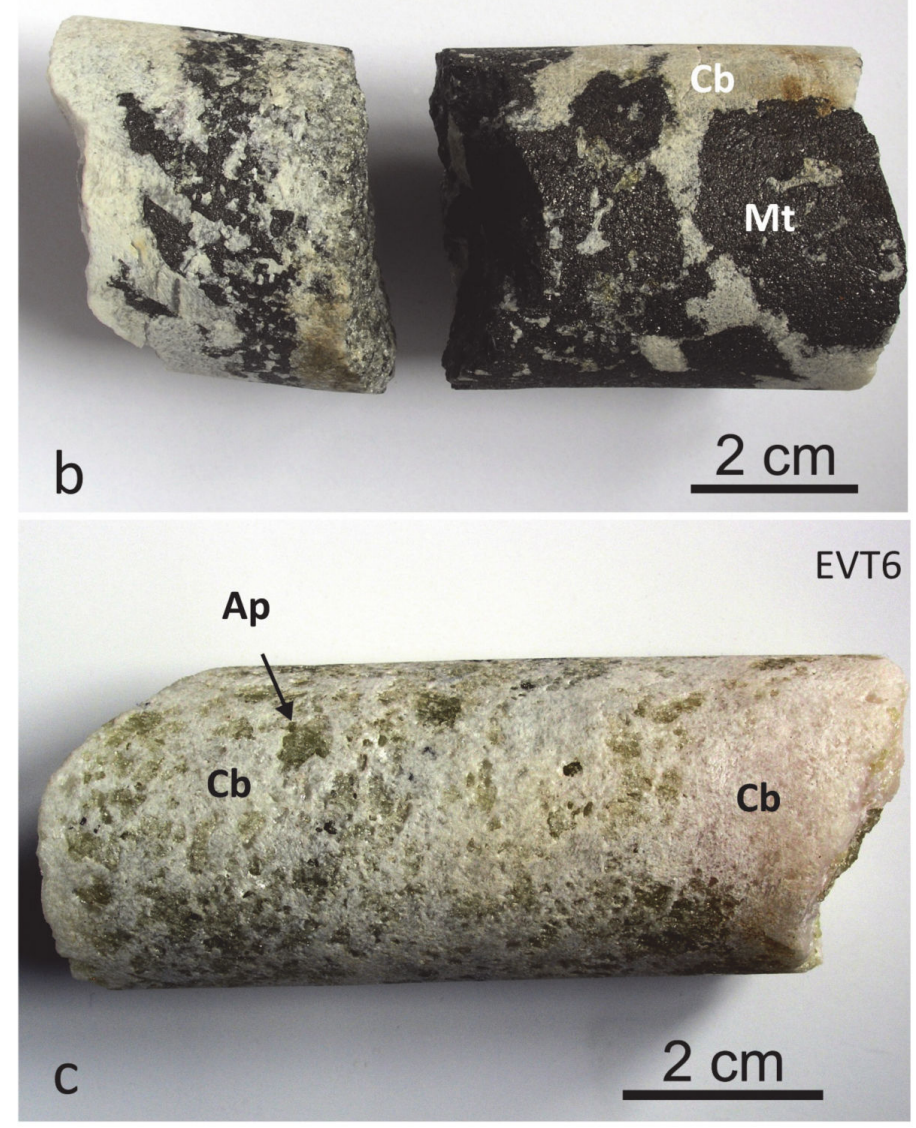

Figure 2. Drill cores of apatite-rich ores from the Evate deposit selected for LA-ICPMS analyses: (a) fresh magnetite-forsterite-apatite-carbonate ore (nelsonite), (b) altered nelsonite dominated by magnetite, and (c) carbonate-anhydrite rock with apatite (carbonatite). Abbreviations: Ap-apatite, $\mathrm{Cb}$-carbonate, $\mathrm{Fo}$ - forsterite, Mt—magnetite. Sample numbers in upper right corners of photographs. 


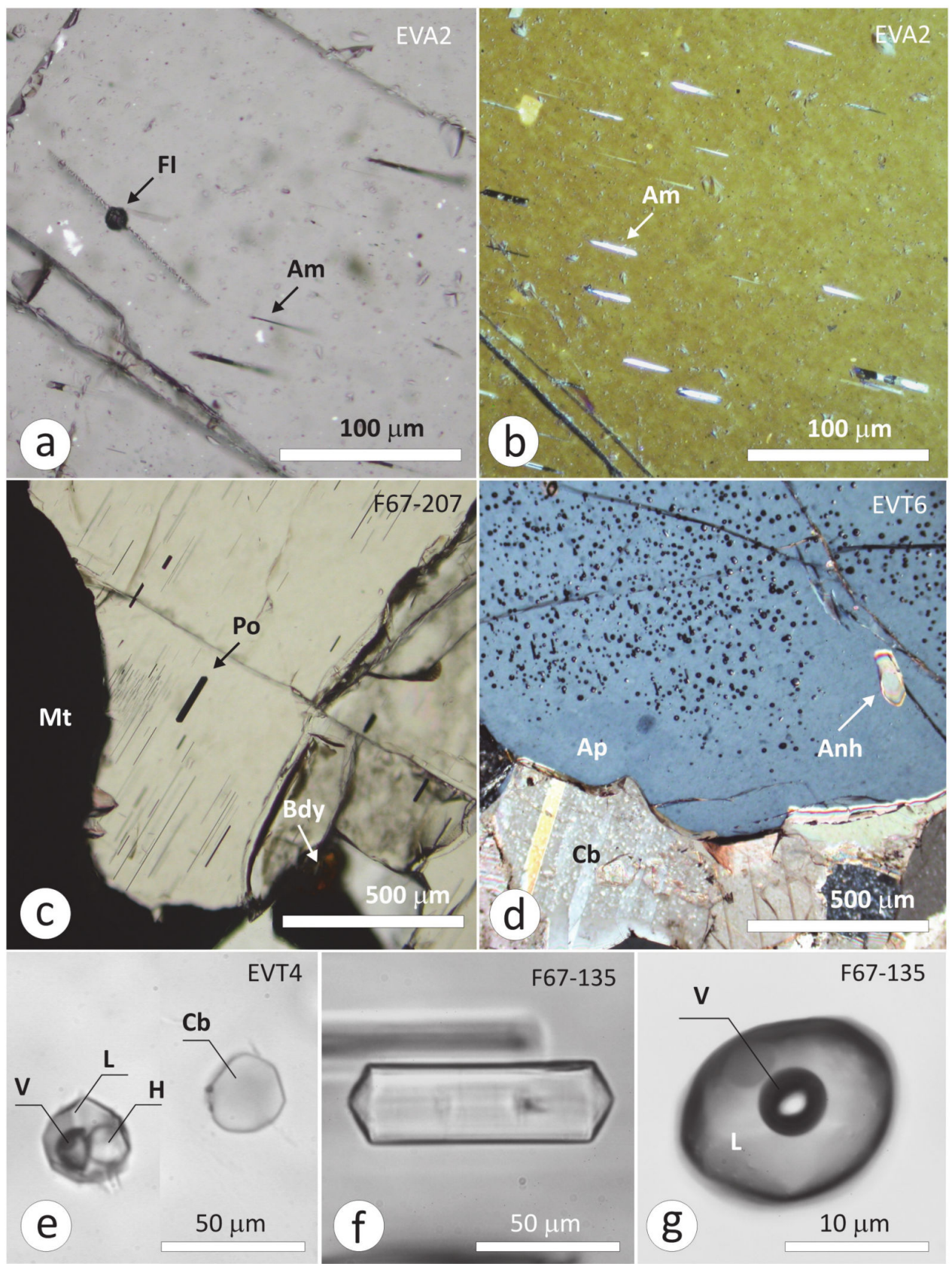

Figure 3. Transmitted light images of fluid and mineral inclusions in apatite from magnetite-forsteritespinel ore $(a-c, e)$ and carbonate ore $(d, f, g)$. (a) Isolated nitrogen inclusion with a re-equilibration crack propagating along c-axis of the host apatite. (b) Transmitted, cross-polarized light image of oriented amphibole inclusions in apatite. (c) Apatite with elongated pyrrhotite inclusions oriented along the c-axis of the apatite host. (d) Transmitted cross-polarized light image of apatite with vacuoles filled with $\mathrm{CO}_{2}$ gas and aqueous fluid, and crystallographically oriented barite-celestite inclusions. (e) Magnified view of coexisting brine and carbonate inclusions. (f) Barite-celestite crystal aligned parallel to the c-axis of host apatite. (g) Rounded two-phase inclusion filled with aqueous liquid (L) and vapor bubble (V). Other abbreviations: Am-amphibole, Anh—anhydrite, Ap—apatite, Bdy-baddeleyite, $\mathrm{Cb}$ - carbonate, $\mathrm{FI}$-fluid inclusion, $\mathrm{H}$ - halite, $\mathrm{Mt}$-magnetite, Po-pyrrhotite. Sample numbers in upper right corners of photomicrographs. 


\section{Results}

\subsection{Cathodoluminescence (CL)}

Different CL-induced colors and zoning types have been observed in investigated apatites. The two nelsonite samples show violet-blue luminescence, grading locally in blue-green colors. The investigated grains are unzoned and subtle changes in CL colors are concentrated on boundaries of strongly cataclased grains (Figure 4).

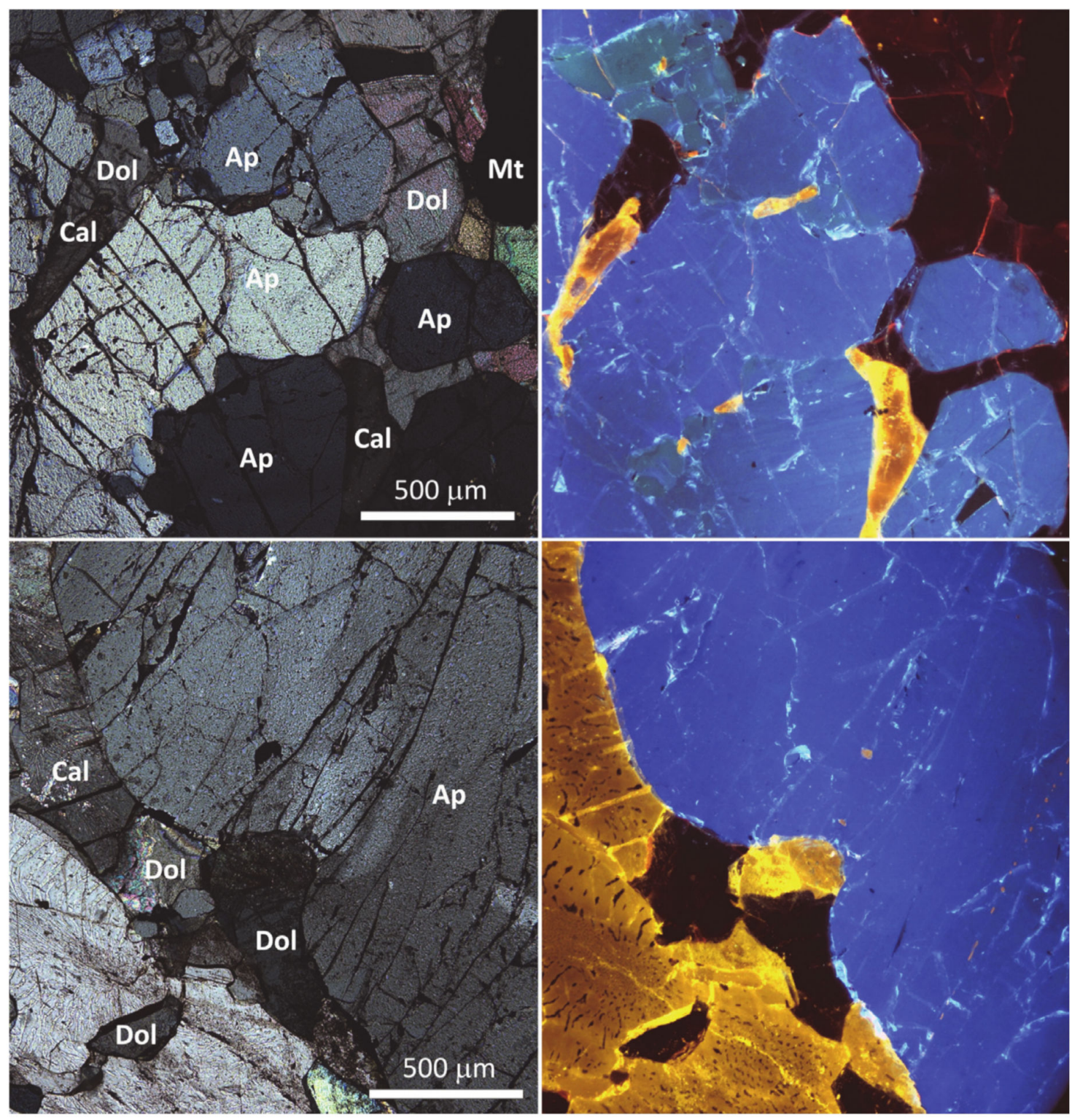

Figure 4. Transmitted cross-polarized light (left column) and cathodoluminescence (right column) images of cataclased apatites from forsterite-magnetite-spinel ores showing dark blue-to-greenish blue cathodoluminescence of apatite (Ap), yellow-to-orange luminescence of calcite (Cal), and dully luminescent dolomite (Dol), the latter discernible as isolated compact anhedral grains and tiny exsolutions in the calcite.

In contrast, carbonatite sample showed oscillatory, patchy domain, and cataclased internal zoning enhanced by alternated brown, blue, grey, and mixed/transient brown-blue luminescence colors (Figure 5). The oscillatory zoning propagates from brown centers towards bluish grain rims. 
Apatite grains with the dominant blue luminescence sometimes show brown sectors or patches around carbonate inclusions. The CL patterns locally suggest time-relative relationships with the blue domains penetrating brown margins or patches as veinlet-like cataclastic textures, suggesting the blue zones postdating the brown ones. Clusters of fluid and sulfate inclusions are concentrated in blue zones, whereas other zones and domains are optically free of fluid and solid inclusions. The zoning in brown and greenish-grey colors most likely represents the primary oscillatory growth pattern, whereas the blue domains with fluid and sulfate inclusions correspond to secondary metasomatic textures resulting from the dissolution-re-precipitation overprinted by the cataclasis and tectonic deformations.

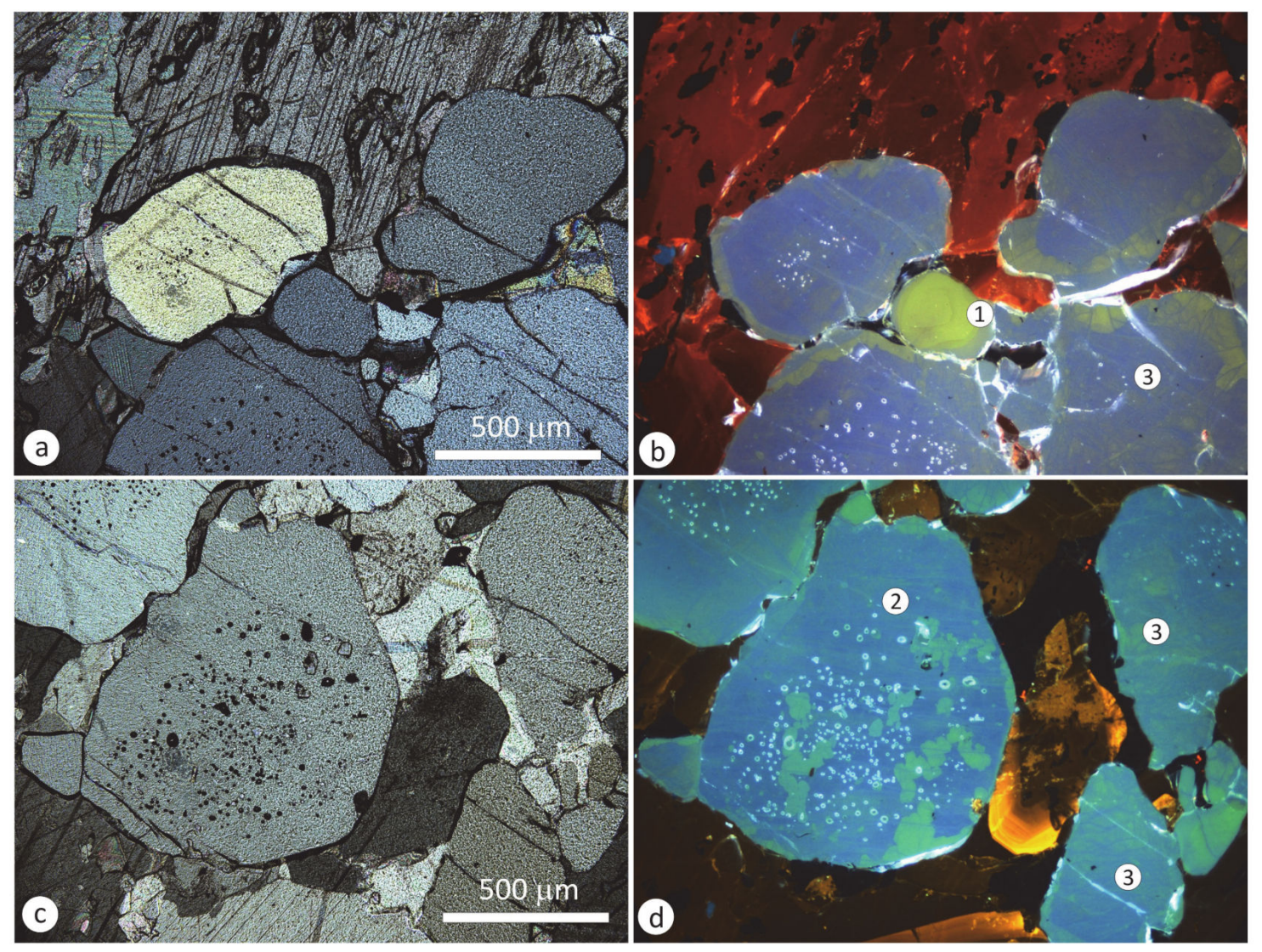

Figure 5. Transmitted cross-polarized light $(\mathbf{a}, \mathbf{c})$ and cathodoluminescence images $(\mathbf{b}, \mathbf{d})$ of apatite from carbonatite EVT6 showing concentric-zoned (1), patchy domain (2), and cataclased (3) textures. Fluid and sulfate inclusions (bright whorls and spots in CL images) are concentrated in grain centers predominantly within blue CL zones. Orange-to-yellow and dully luminescent grains correspond to calcite and dolomite, respectively.

\subsection{Electron Probe Micro-Analysis (EPMA)}

Apatite was studied by electron probe micro-analysis in a total of 15 drill cores (Supplementary Materials Table S1). Despite a large variability of CL zonings and inclusions, chemical compositions of apatites from carbonatite and nelsonite show only negligible variations. Ca contents ranged from 38.2-39.7 wt. \%, with a median value of 39.17 wt. \%. With fluorine as a dominant anion (1.03-1.47 apfu, 1.95-2.75 wt. \%), all apatites can be classified as fluorapatite (Figure 6). 


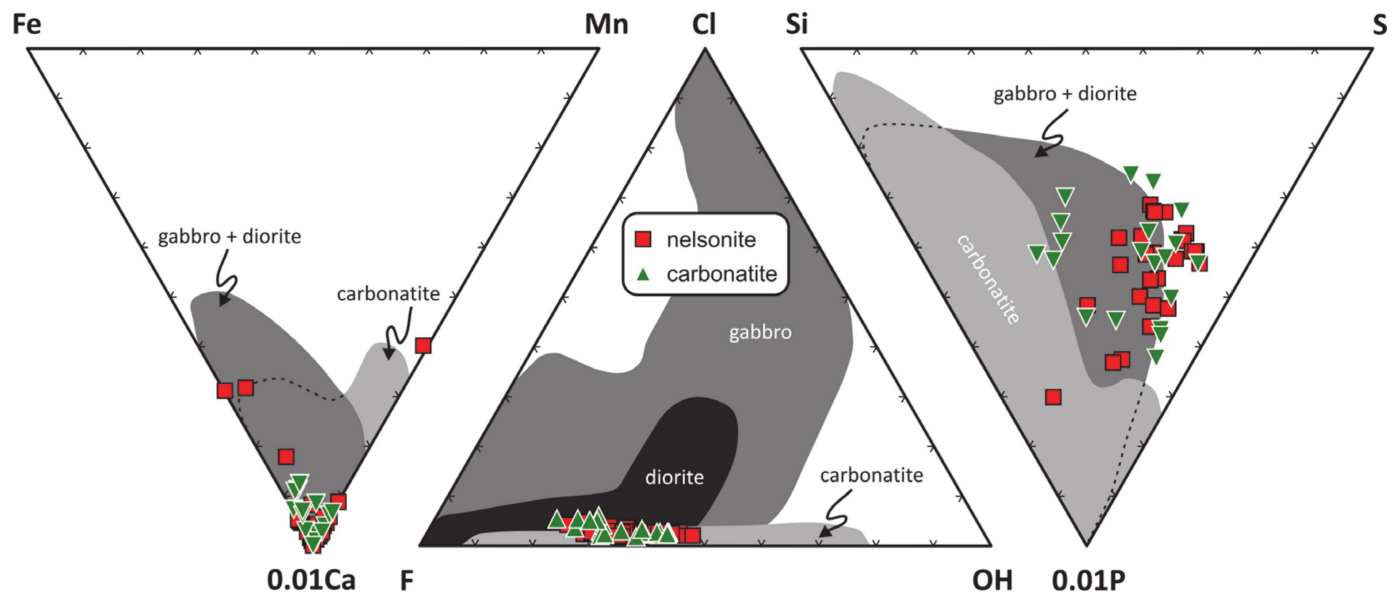

Figure 6. Triangular plots correlating elemental ratios (apfu) in $A$ - (left diagram), $T$ - (right diagram), and $(\mathrm{OH}, \mathrm{F}, \mathrm{Cl})$-sites (middle diagram) in apatites from Evate deposit with compositional fields for carbonatites, diorites, and gabbros from [25].

Careful screening of EPMA data showed small differences between the two types of apatite-bearing ores. Carbonatite apatites show locally increased Si contents compared to those from nelsonites. Calculated carbon contents are somewhat higher in nelsonite apatites (up to $0.26 \mathrm{apfu}$, the median value of $0.064 \mathrm{apfu}$ ) compared to carbonatites (up to $0.12 \mathrm{apfu}$, the median value of $0.002 \mathrm{apfu}$ ). $\mathrm{Na}_{2} \mathrm{O}$ contents are uniform and generally vary within the range of $0.03-0.33 \mathrm{wt}$. \%. Sulphur contents are scattered within the range of $0.02-0.32 \mathrm{wt}$. \% in both rock types, and are locally enriched compared to other carbonatites worldwide, where it is generally less than $0.2 \mathrm{wt}$. \% [26].

All investigated apatites are characterized by the dominant belovite substitution, showing $\mathrm{Na}, \mathrm{Sr}$, and REE replacement for Ca (Figure 7a). Limited cesanite substitution, i.e., replacement of phosphate ions by sulfate with the charge difference compensated by replacing calcium with sodium, is also present, judging from the positive correlation between $\mathrm{Na}$ and $\mathrm{S}$ and the negative correlation between $\mathrm{Ca}$ and $\mathrm{S}$ (Figure $7 \mathrm{~b}, \mathrm{c}$ ). Other substitutions have not been recognized.
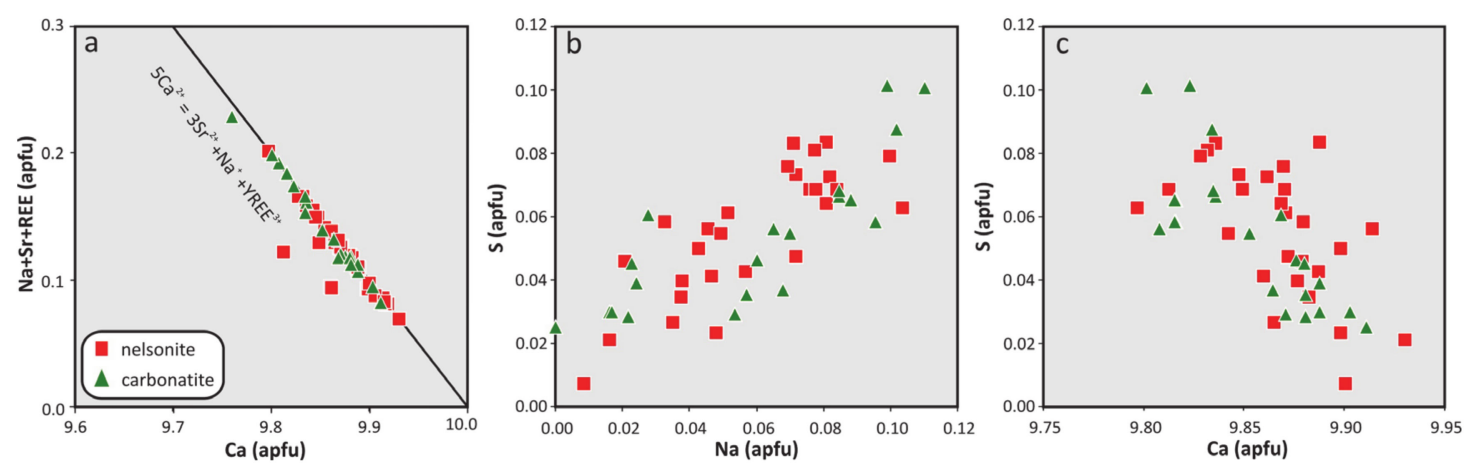

Figure 7. Main substitutions in fluorapatites from the Evate deposit derived from EPMA data. (a) The belovite-type substitution. Positively correlated $\mathrm{Na}$ and S (b) and negatively correlated $\mathrm{Ca}$, and S (c) indicate the subordinate cesanite-type substitution.

\subsection{In-Situ Laser Ablation (LA-ICPMS)}

Statistical analysis of LA-ICPMS data (Supplementary Materials Table S2) shows Fe, Sr, Y, Ba, Ce, Th, and $U$ fluctuations within the largest range (considering standard deviation) in the apatite from carbonatite EVT6 showing the highest absolute contents of Fe (343 ppm), Sr (9,073 ppm), Y (258 ppm), $\mathrm{Ba}(14 \mathrm{ppm})$, and REE (7,738 ppm). Average total REE contents in apatites tend to increase from fresh 
nelsonite $(0.19 \mathrm{wt}$. \% of elements), through altered nelsonite $(0.35 \mathrm{wt} . \%)$, to carbonatite $(0.45 \mathrm{wt}$. \%). Heavy REE (Ho-Lu) are low in all apatites, with maximum contents up to $26 \mathrm{ppm}$ each.

Except for Mn and $\mathrm{U}$, the average contents of trace elements in the carbonatite EVT6 are above the mean calculated from all analyses (Figure 8). Y and REE contents in the altered nelsonite EVT8 are also above the mean, whereas $\mathrm{Mn}, \mathrm{Fe}, \mathrm{Sr}$, and Ba contents are moderately depleted. Significantly lower, by more than $1 \sigma$, are $\mathrm{U}, \mathrm{Th}$, and $\mathrm{Pb}$ contents. Trace element contents in apatites from fresh nelsonite EVT2 follow the opposite trend: $\mathrm{Mn}, \mathrm{Ba}, \mathrm{U}, \mathrm{Th}$, and $\mathrm{Pb}$ are enriched, and other elements are depleted compared to the altered nelsonite. The distribution of the average REE contents below the overall average has a very balanced pattern along with $\mathrm{Y}$, which, however, shows the highest negative deviation and the lowest content of $32 \mathrm{ppm}$.

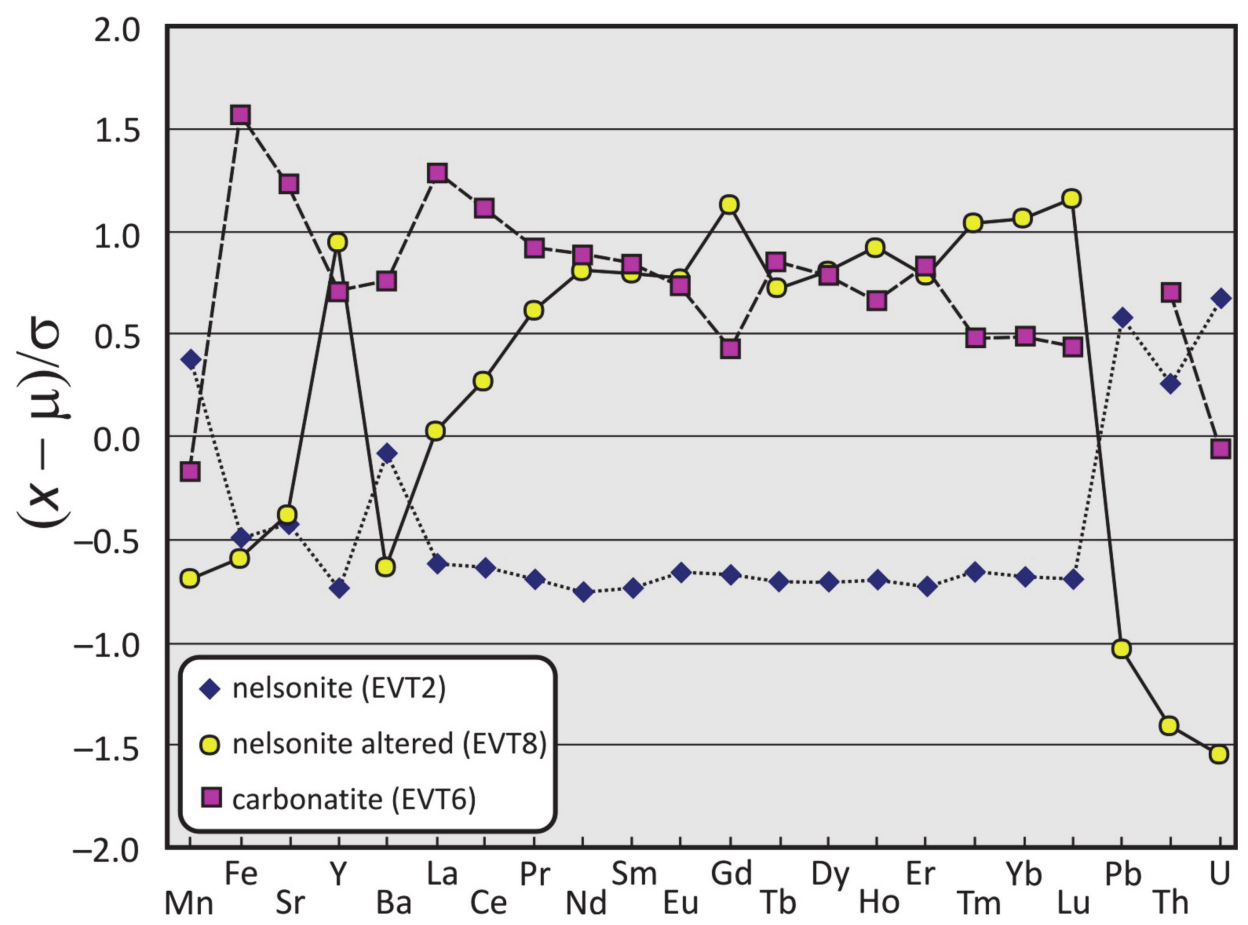

Figure 8. Relative trace element concentration data on Evate apatites expressed as a standardized score $z=(x-\mu) / \sigma$, where $x$ is the observed value, i.e., the mean of a particular sample, $\mu$ is the mean of all investigated samples, and $\sigma$ stands for the standard deviation.

Subtle differences among investigated ore types are also discernible in diagrams correlating concentrations of element pairs. Low concentrations of $\mathrm{Pb}$, Th, and $\mathrm{U}$ in altered nelsonites (up to 6, 14 and $2 \mathrm{ppm}$, respectively) contrast with other samples (up to 9,97 and $11 \mathrm{ppm}$, respectively). Th/U ratios tend to increase from $~ 5: 1$ in nelsonite to $\sim 10: 1$ in carbonatite (Figure 9a). Some extremely high $\mathrm{Th} / \mathrm{U}$ ratios in the altered nelsonite result from a large uncertainty of low $U$ contents, being close to the detection limit. The determined $\mathrm{Th} / \mathrm{U}$ ratios overlap the normal range from 3 to 30 in pyrochlore-free carbonatites [27]. 

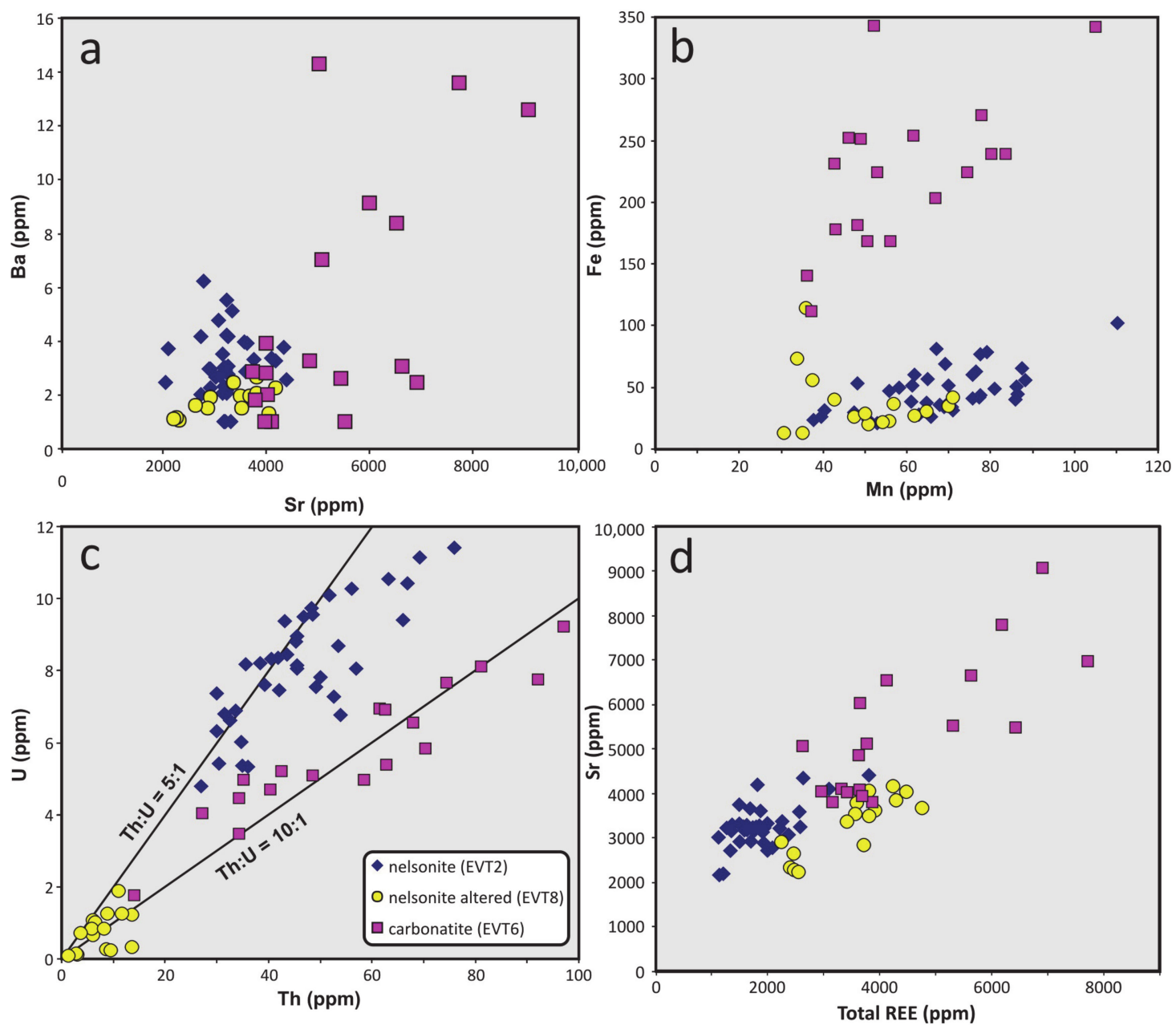

Figure 9. Correlation diagrams for selected elements determined by LA-ICPMS, showing the lacking correlations between $\mathrm{Sr}-\mathrm{Ba}(\mathbf{a}), \mathrm{Mn}-\mathrm{Fe}(\mathbf{b})$, and positive correlations between Th-U (c) and total REE-Sr (d).

The small variance of Mn values (30-70, up to $110 \mathrm{ppm}$ ) is consistent with the small variance of average values as opposed to Fe (Figure $9 \mathrm{~b}$ ). This element shows the large variance with maximum values in carbonatites (112-343 ppm), while fresh and altered nelsonites have lower concentrations between 20-102 ppm and 13-114 ppm, respectively. The lack of Sr and Ba correlation (Figure 9c) indicates that increased Sr contents in the carbonatite EVT6 are unrelated to barite-celestine inclusions. Figure $9 \mathrm{~d}$ documents that the increasing REE concentration in hydrothermally altered nelsonite and carbonatite is correlated with the increasing Sr content. Changes in the contents of these elements are somewhere reflected in the BSE images, showing darker grain centers and lighter marginal zones. Similar textures have been found in apatite grains in the Aley deposit, Canada [27].

Chondrite-normalized REE patterns are characterized by enrichment in LREE (La-Sm) typical of carbonatites worldwide, and the depletion in La compared to other LREE (Figure 10). Diagnostic is also insignificant $\mathrm{Eu}_{\mathrm{cn}}$ anomalies in all samples $\left(\mathrm{Eu} / \mathrm{Eu}^{*}=\mathrm{Eu}_{\mathrm{cn}} / 0.5\left(\mathrm{Sm}_{\mathrm{cn}}+\mathrm{Gd}_{\mathrm{cn}}\right)=0.70-1.39\right)$, and moderately positive $\mathrm{Gd}_{\mathrm{cn}}$ and $\mathrm{Er}_{\mathrm{cn}}$ anomalies in the altered nelsonite and carbonatite. The fluctuation in Eu content is somewhat larger than in typical carbonatites, showing the $\mathrm{Eu} / \mathrm{Eu}^{*}$ ratios from 0.85 to 1.16 [27]. 

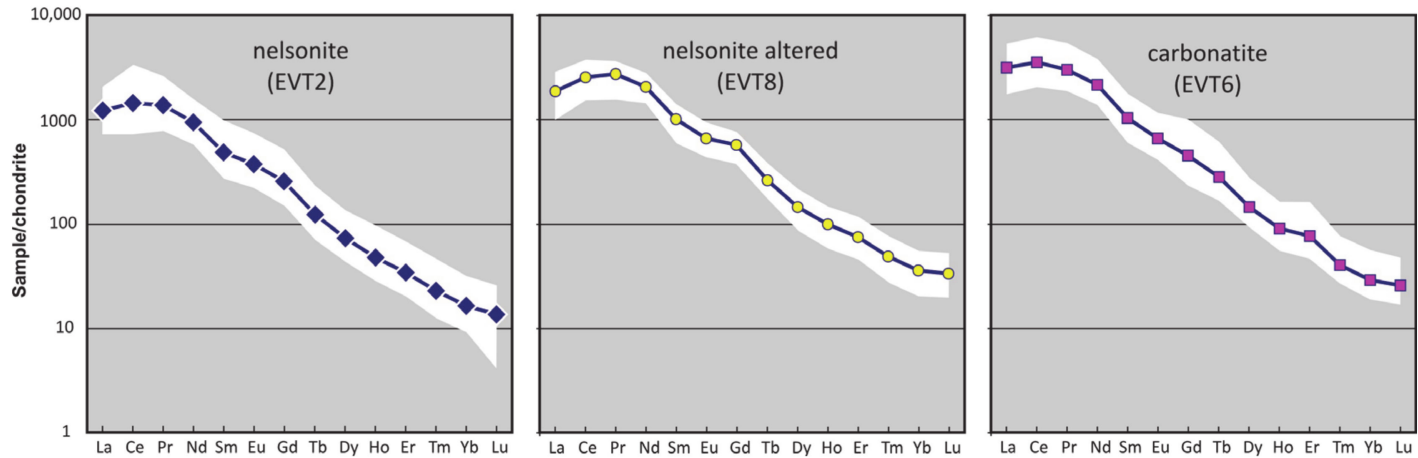

Figure 10. Chondrite-normalized [45] REE patterns of apatite from Evate showing the mean values and range contours.

Changes in the geochemistry of apatites with various internal textures have been investigated using areal LA-ICPMS imaging (Figure 11) and pointed analyses (Figure 12). The elemental imaging of nelsonite apatite with relatively uniform violet-blue CL texture (CL-A) shows the rather asymmetric distribution of rare earth elements. In contrast, the carbonatite apatite with primary growth zoning (CL-B) exhibits a higher concentration of some REE in the blue CL-zone compared to the middle part (Figure 11). Similar growth zoning was reported in apatite from Neoproterozoic Matongo carbonatite (Burundi) [46].
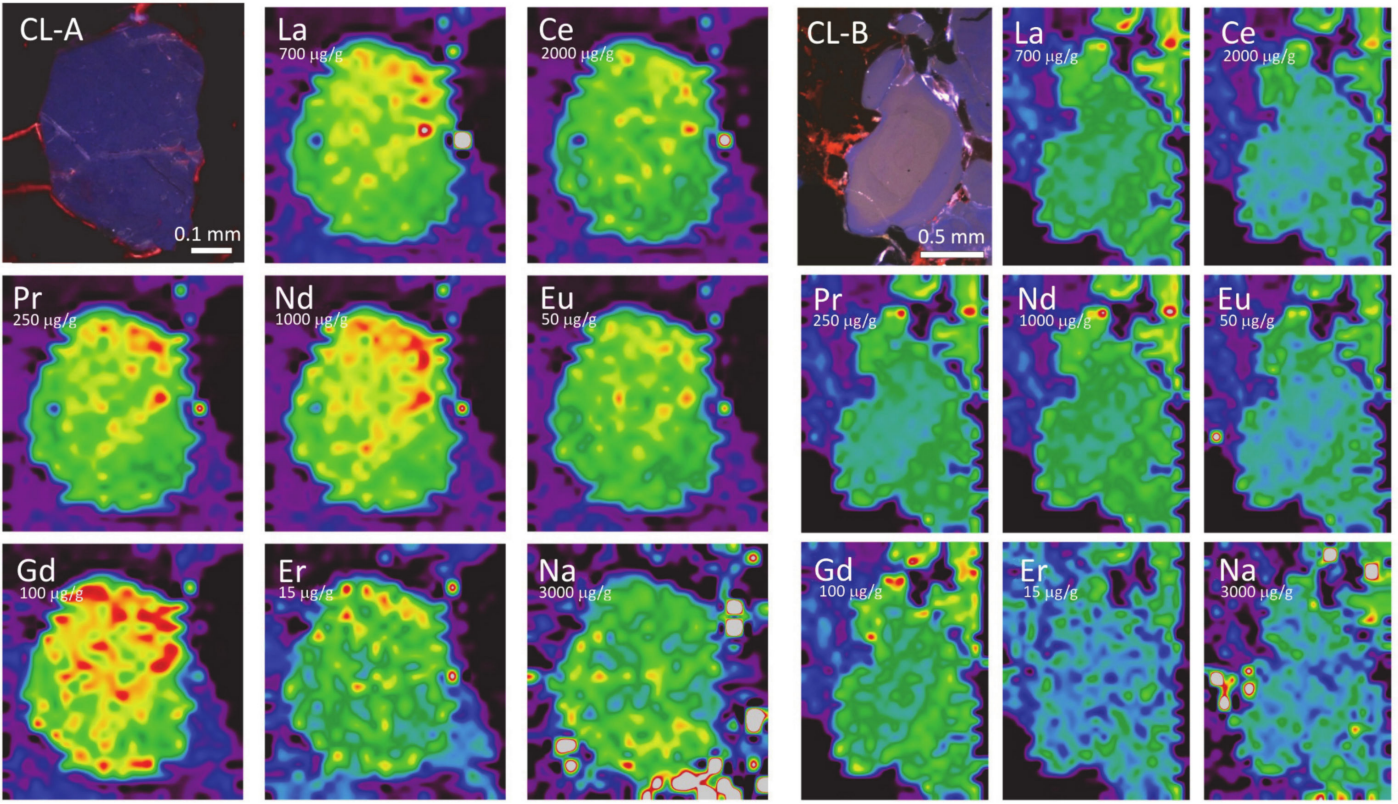

Figure 11. Cathodoluminescence (CL) images of apatite from magnetite-forsterite-spinel nelsonite (CL-A) and carbonatite (CL-B) complemented with elemental distribution maps obtained using LA-ICPMS. The apatite grain A (fresh nelsonite EVT2) shows relatively homogenous blue-violet $\mathrm{CL}$, contrasting with the inhomogeneous distribution of rare earth elements, showing gradually increasing concentrations towards the upper grain portion. The carbonatite apatite with primary growth zoning shows lower REE concentrations in greenish-grey luminescent zones compared to blue ones. Warmer colors correspond to a higher concentration of the respective element. Maximum element concentrations are indicated. 

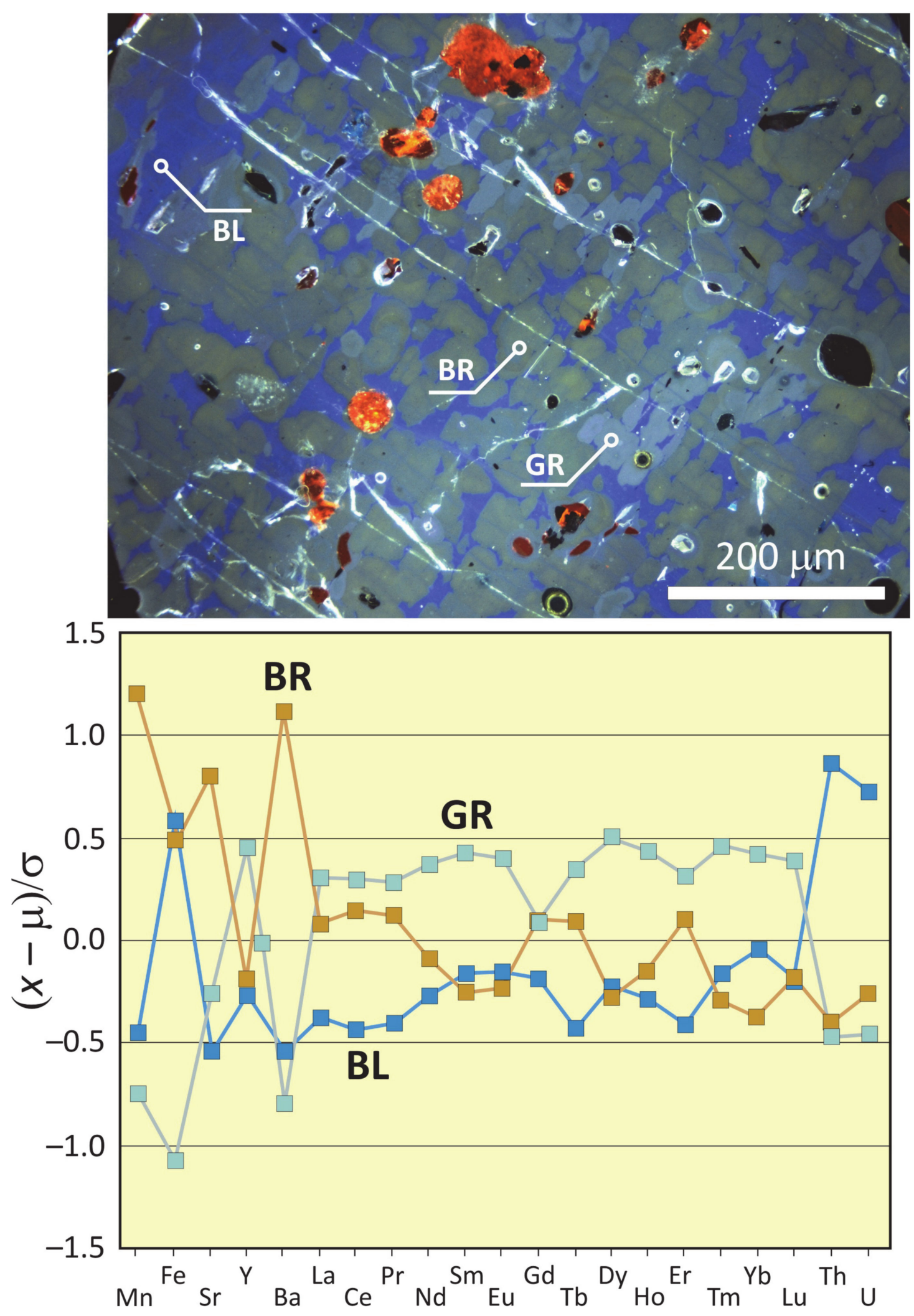

Figure 12. Comparison of average elemental concentrations in blue (BL), greenish-brown (BR), and grey (GR) fluorescing CL-domains in hydrothermal-metasomatic apatite (carbonatite EVT6) expressed in terms of the standardized score $z=(x-\mu) / \sigma$. Orange-luminescent areas in the CL image correspond to calcite. 
Pointed LA-ICPMS analyses yielded overlapping ranges of element concentrations in various colored CL domains in patchy zoned apatite (Figure 12) except for greenish-brown domains invariably enriched in $\mathrm{Ba}$ and $\mathrm{Mn}$ and grey zones depleted in Fe. REE contents tend to increase from blue through brown to grey domains, but determined ranges fluctuate considerably in each zone. Th and $\mathrm{U}$ concentrations reach the maxima in blue domains, and they exhibit sharp fluctuations in greenish-brown domains. Fe behaves ambivalently, reaching the highest concentrations in blue and greenish-brown domains, and the lowest concentrations in grey zones. Although there are some differences and variability in the concentrations of minor elements in individual CL-domains, these are not reflected in always homogeneous BSE contrasts.

The CL spectra of Evate apatite (Figure 13) show a broad peak at $375-450 \mathrm{~nm}$ associated with sharp peaks at $485 \mathrm{~nm}\left(\mathrm{Dy}^{3+}\right), 599 \mathrm{~nm}\left(\mathrm{Sm}^{3+}\right), 643 \mathrm{~nm}\left(\mathrm{Eu}^{3+}+\mathrm{Sm}^{3+}\right)$, and a series of small unidentified peaks between $680-820 \mathrm{~nm}$. The doublet at $575 \mathrm{~nm}$ corresponds to $\mathrm{Eu}^{3+}, \mathrm{Dy}^{3+}$, and $\mathrm{Sm}^{3+}$ combined with $\mathrm{Mn}^{2+}$, whereas $\mathrm{Eu}^{3+}$ bands are located at 585, 613, and $645 \mathrm{~nm}$. Minor $\mathrm{Ce}^{3+}$ emission band is located at $432 \mathrm{~nm}$. There is no qualitative difference between the greenish-brown and blue fluorescing domains, except for different peak intensities, and the shape of the band at $375-450 \mathrm{~nm}$.

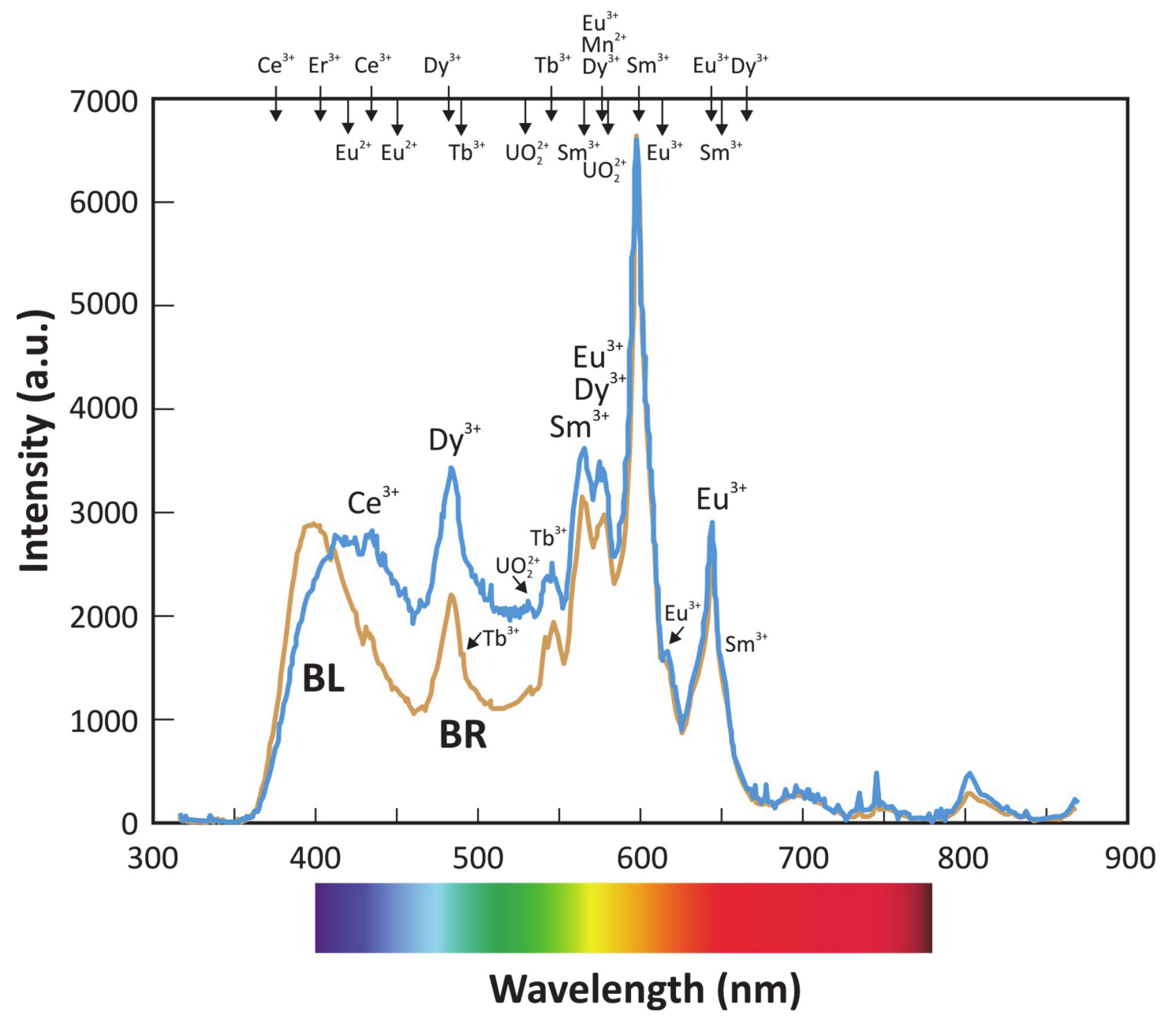

Figure 13. Cathodoluminescence (CL) spectra of hydrothermal-metasomatic apatite (sample EVT6) collected by an optical spectrometer. BR and BL denote greenish-brown and blue fluorescing CL domains, respectively, shown in Figure 12. Peak identification after [47-49]. Spectra are normalized to the equal intensity of the $\mathrm{Sm}^{3+}$ band at $599 \mathrm{~nm}$. 


\section{Discussion}

EPMA revealed a surprisingly uniform composition of apatite in the Evate deposit regardless of the ore type, CL texture, and the character of fluid and mineral inclusions. All investigated apatites correspond to fluorapatite, which is the dominant apatite type of volcanic-plutonic igneous systems $[22,23,26]$. The major element composition of fluorapatite from Evate is similar to carbonatites worldwide, including phoscorites and sövite-ijolite rocks, with Ca contents scattered within the range from 37.0 to $39.8 \mathrm{wt}$ \% and the median value of $38.8 \mathrm{wt}$. \%. EPMA analyses plot along the OH-F join typical of carbonatites. Negligible Mn and Fe concentrations are also consistent with other carbonatites, although the P-Si-S ratios plot outside the carbonatite field (Figure 6) and the calculated TSI indices (0.7-7.2) are significantly lower compared to those in typical carbonatites, showing TSI mostly in the range of $7.9-48$ [16].

Various discrimination diagrams can be employed to constrain the origin of apatite. The diagram in Figure 14 is based on the statistical parameters DP1-1 and DP1-2 calculated from trace elements concentrations in ppm [27]:

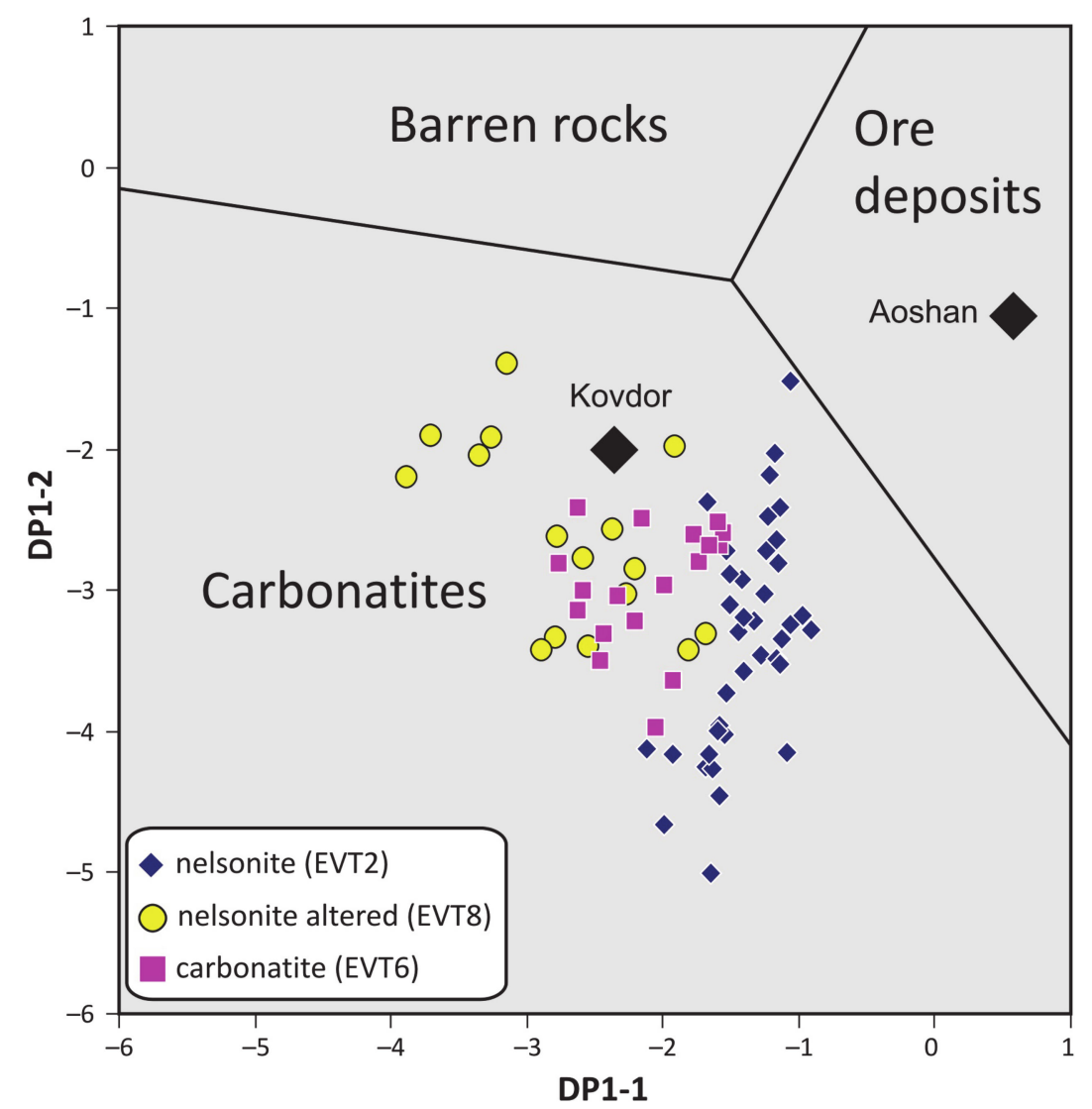

Figure 14. Discrimination diagram for apatites [27] with projection points of LA-ICPMS analyses from Evate, and median apatites from the Kovdor carbonatite (Russia) and the Kiruna-type apatite-magnetite deposit of Aoshan (China). The meaning of DP1-1 and DP1-2 parameters is explained in the text.

DP1-1 = -0.06461logMn $-1.55971 \operatorname{logSr}+2.60894 \log \mathrm{Y}+0.36314 \log \mathrm{La}-1.76617 \log \mathrm{Ce}+$ $0.62425 \log \mathrm{Eu}-3.64151 \log \mathrm{Dy}+0.70865 \log \mathrm{Yb}-1.17835 \log \mathrm{Pb}+0.41613 \log \mathrm{Th}+0.96296 \log \mathrm{U}+6.58860$;

$\mathrm{DP} 1-2=0.20726 \log \mathrm{Mn}-1.03478 \log \mathrm{Sr}+15.10377 \log \mathrm{Y}+4.99528 \log \mathrm{La}-5.80367 \log \mathrm{Ce}+$ $0.17409 \log \mathrm{Eu}-8.77133 \log \mathrm{Dy}-4.32634 \log \mathrm{Yb}+2.02248 \log \mathrm{Pb}-0.67191 \log \mathrm{Th}+0.02096 \log \mathrm{U}-10.44899$.

This diagram separates compositional fields of carbonatites, phoscorites, and associated ijolites from apatite-bearing ore deposits, including the iron-oxide-apatite (IOA) deposits, and barren rocks. Our LA-ICPMS data on Evate apatites invariably plot within the field of carbonatites. This affiliation is 
further justified by chondrite-normalized REE patterns without pronounced Ce and/or Eu anomalies (Figure 10), being thus similar to apatites from the Kovdor carbonatite-phoscorite complex [50].

Diagram in Figure 15 discriminates apatites from mafic and felsic igneous rocks, lherzolites, granites, pegmatites, and carbonatites. Our LA-ICPMS data plot close to or within the compositional fields of carbonatites and lherzolites, far away from the fields of IOA deposits, mafic igneous, and granitic rocks. Typical of the Evate apatite is a moderate displacement from the carbonatite field in the discrimination diagrams based on $\mathrm{Y}$ and REE, reflecting the depletion in these elements in the Evate ores compared with other carbonatites.
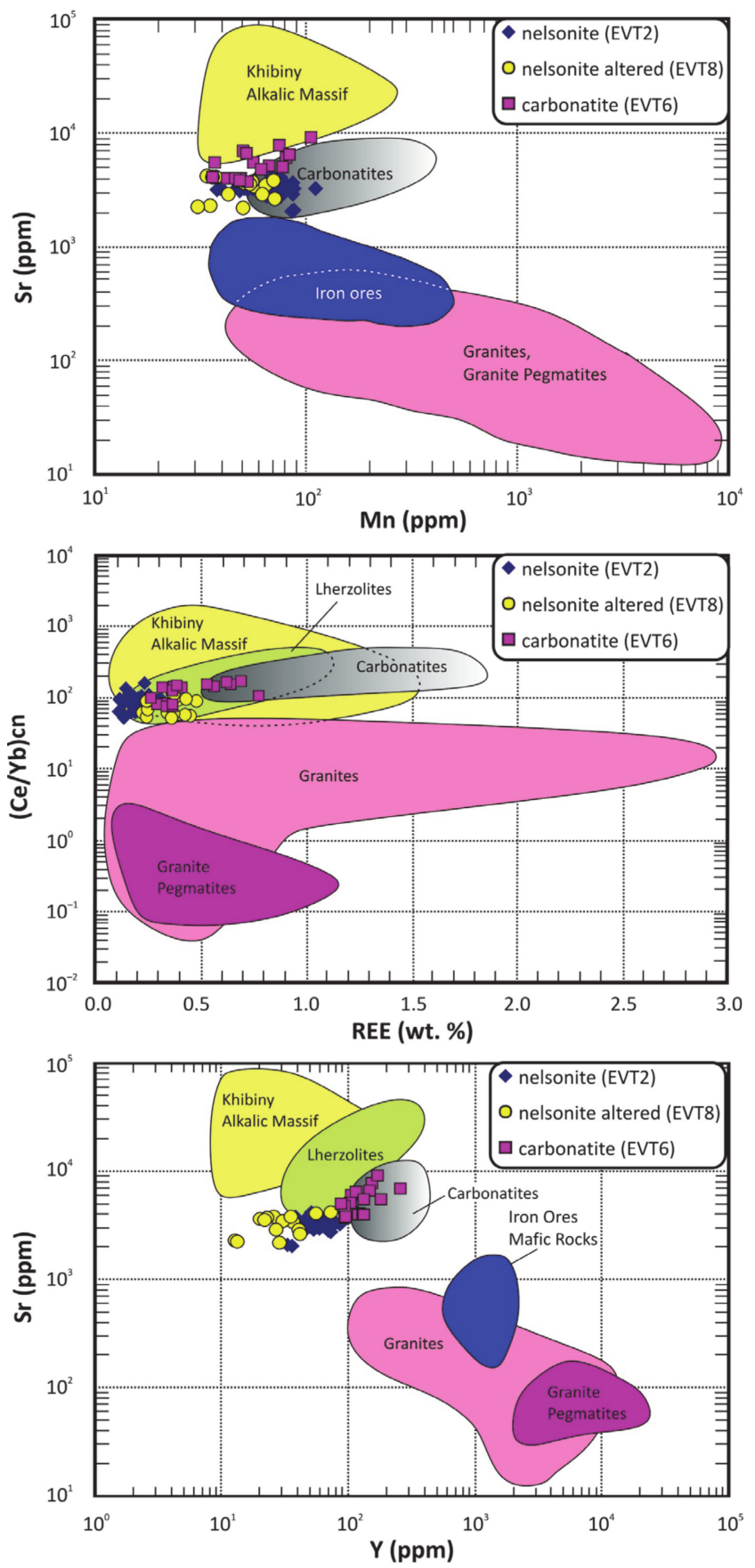

Figure 15. Discrimination diagrams for various genetic types of apatites [26] with projection points of apatites from Evate supplemented by the compositional field of apatite from the Khibiny nepheline syenite massif with minor carbonatites constructed from analyses published in [51]. 
Projection points of Evate apatites in the discrimination diagram correlating $\delta \mathrm{Eu} / \delta \mathrm{Y}$ parameters (Figure 16) cluster within the compositional field of magmatic carbonatites and phoscorites, proximal to hydrothermal apatites associated with carbonatites. An overlap with Fe-oxide-apatite (IOA) deposits can be seen especially in the case of altered nelsonite (EVT8). Our data also plot in the proximity of some African carbonatites. The position of nelsonite apatite (EVT2) extends to higher $\delta$ Eu values above the magmatic apatite field, indicating an environment with a limited melt/fluid differentiation.

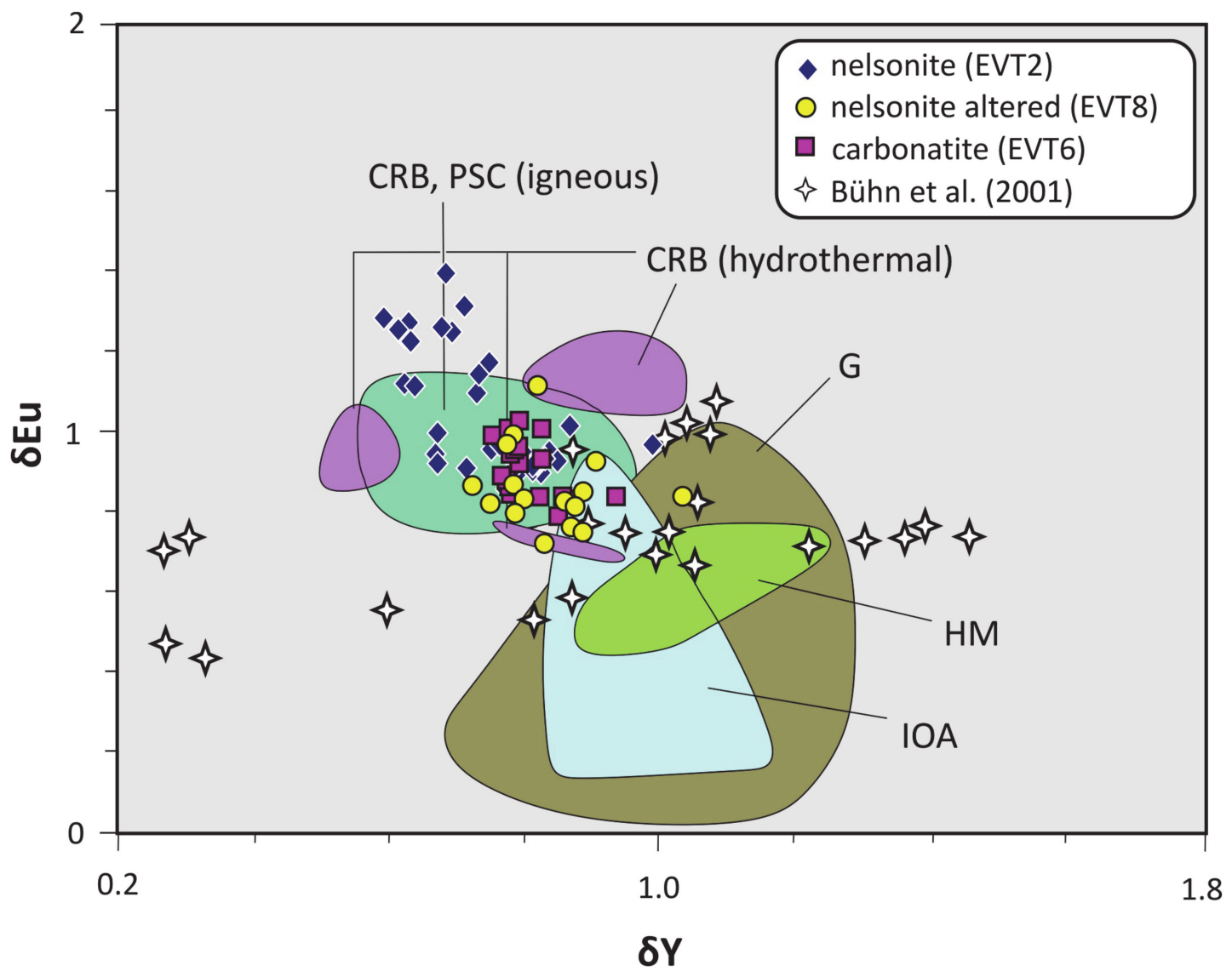

Figure 16. $\delta \mathrm{Y}=\mathrm{Y}_{\mathrm{cn}} /\left(0.25 \mathrm{Dy}_{\mathrm{cn}}+0.75 \mathrm{Ho}_{\mathrm{cn}}\right)$ versus $\delta \mathrm{Eu}=\mathrm{Eu}_{\mathrm{cn}} / 0.5\left(\mathrm{Sm}_{\mathrm{cn}}+\mathrm{Gd}_{\mathrm{cn}}\right)$ discrimination diagram [28] with data from Evate and compositional fields of apatites from different rocks suites and deposits: African carbonatites [24], igneous and hydrothermal carbonatites (CRB), phoscorites (PSC), granitoids $(\mathrm{G})$, granitic pegmatites (GP), hydrothermal-metasomatic rocks (HM), and iron-oxide-apatite deposits (IOA) [52-57].

$(\mathrm{La} / \mathrm{Yb})_{\mathrm{cn}}$ ratios are used as another criterion for the deciphering the magmatic or hydrothermal apatites and the assessment of the differentiation degree of the carbonatite melt. The $(\mathrm{La} / \mathrm{Yb})_{\mathrm{cn}}$ ratio of 30-500 is reported for igneous apatites, contrasting with $\leq 25$ in hydrothermal varieties [28,58]. Early apatites maintain the ratio below 100, whereas the latter ones are above 100 [24]. The Evate apatites from fresh (EVT2) and altered (EVT8) nelsonites exhibit the (La/Yb) $\mathrm{cn}$ ratios of 53-93 and 32-83, respectively, thus falling within the range diagnostic for early apatites. In contrast, the apatite from carbonatite EVT6 with the $(\mathrm{La} / \mathrm{Yb})_{\mathrm{cn}}$ ratio of 78-144 partly overlaps the interval of late apatites crystallized from more differentiated melts.

There are also additional criteria favoring the magmatic origin of apatites studied. These include Sr contents ranging from 2062 to 4405 ppm in nelsonite and up to 4178 ppm in altered nelsonite, contrasting with higher contents, 3741-9073 ppm, and the larger extent in the carbonatite. The values above 2000 ppm Sr are diagnostic for igneous apatites [28]. Likewise, low Mn contents in Evate apatites 
(30-110 ppm) coincide with the range of 50-1000 ppm, typical for the Vishnevye Gory deposit in Russia and the Oka deposit in Canada [28].

Magmatic origin of the Evate apatite is also supported by slightly positive $\delta \mathrm{Ce}$ anomalies averaging at 1.11, with a total range of $0.85-1.45$. The positive Ce anomalies in Evate differ from typical negative anomalies in hydrothermal apatites of the Kovdor phoscorite $(\delta \mathrm{Ce}=0.2-0.8)$ or the typical value of 0.77 in the apatite from alteration zones of the Turiy Mys carbonatite [28]. On the other side, however, our values overlap with the slight $\mathrm{Ce}$ enrichment $(\delta \mathrm{Ce}=1.2)$ observed in the magmatic apatite from Laiwu-Zibo carbonatites of the Shandong Province in China [59]. It should be noted that low Mn contents in Evate apatites are reminiscent of hydrothermal apatites from Afrikanda, Kovdor, and Aley [60,61].

Apatite favors the incorporation of $\mathrm{Eu}^{3+}$ and $\mathrm{Ce}^{3+}$ over $\mathrm{Eu}^{2+}$ and $\mathrm{Ce}^{4+}$, because radii of the trivalent REE's are very close to that of $\mathrm{Ca}^{2+}$ [62]. As a consequence, apatites crystallized in more oxidizing conditions would have higher $\mathrm{Eu}$ and lower Ce compared to those precipitating in the more reduced conditions. The fluctuating redox conditions are, however, not unequivocally reflected in Eu and Ce concentrations determined by LA-ICPMS, showing no antithetic behavior (Figures 8 and 12).

Hydrothermal alterations result in the variability of cathodoluminescence-induced colors in Evate apatites. Interestingly, relatively well-pronounced CL-zones do not have their counterparts in BSE contrasts, where little or no variability was observed. These findings are different from the published studies on zonal apatites from carbonatites [28], where differences in BSE and CL contrasts reflect concentration changes in LREE, Dy, and Mn. From this one can deduce that CL-contrasting domains in the Evate carbonatite are caused by the combination of elements with small differences against the atomic weight of major elements in apatite.

Blue-luminescent rims around oscillatory-zoned cores should be directly linked with hydrothermal alteration, as it is indicated by abundant sulfate and fluid inclusions (Figure 5). Similar CL-zoning, albeit without inclusion, has been documented in apatites from the Palaborwa (South Africa) [63] and Matongo (Burundi) [46]. However, unequivocal identification of activators responsible for the variable CL-emissions is problematic [64]. Published data show that major variations in the apatite luminescence are associated with the combination of $\mathrm{Mn}^{2+}$ and different divalent and trivalent REE's [64-66]. The variegated CL colors are often attributed to a specific combination of several activators or elements. For example, the violet-blue luminescence, fairly similar to that observed in nelsonite apatites from Evate, is typical for Mn-poor apatites activated by $\mathrm{Eu}^{2+}$, whereas green $\mathrm{CL}$ colors may be emitted by $\mathrm{Dy}^{3+}$. Yellow to greenish-yellow luminescence pertains to the $\mathrm{Mn}^{2+}$ emission in REE-poor material [28]. Brown CL-emissions composed of purple, green, and violet-red components can also be associated with $\mathrm{Ce}^{3+}$ and $\mathrm{Tb}^{3+}$ supplemented by $\mathrm{Dy}^{3+}$ and $\mathrm{Sm}^{3+}$ [66]. Interplay between green components of $\mathrm{Mn}^{2+}$ and $\mathrm{Dy}^{3+}$ and the red emission of $\mathrm{Sm}^{3+}$ produces almost all diverse CL colors of apatite, involving purple, blue-green, reddish-brown, and greyish colors (A. Chakhmouradian, pers. comm.).

The generally low Mn content in apatite from Evate carbonatite is well reflected in CL-spectra, where a broad $\mathrm{Mn}^{2+}$-emission band at $565 \mathrm{~nm}$ [64] is missing or overwhelmed by intense $\mathrm{Eu}^{3+}$ and $\mathrm{Dy}^{3+}$ emissions even in the brown (BR) domain relatively enriched in Mn compared to blue (BL) and grey (GR) domains (Figures 12 and 13). Hence, the observed color variations are probably induced mainly by fluctuations of REE activators, to a lesser extent also by Mn in GR domains, and U in Mnand REE-depleted BL domains.

The Th/U variations between CL zones in hydrothermally overprinted apatite and between fresh and altered nelsonites (Figure 9) reflect the oxidation and partial removal of $\mathrm{U}^{4+}$ from the apatite structure during the interaction with oxidizing aqueous fluids capable of transporting soluble $\mathrm{U}^{6+}$. Oxidizing fluids and especially the $\mathrm{Ce}^{4+}$ stability during the hydrothermal alteration of the Evate carbonatite has been directly proven by the identification of cerianite closely associated with sulfates in carbonatite from drillcore F-59/95 m. Uranium can act as the luminescence activator only as $\mathrm{U}^{6+}$ or uranyl ion $\mathrm{UO}_{2}{ }^{2+}$, but not as $\mathrm{U}^{4+}$ [67]. The uranyl $529 \mathrm{~nm}$ band is also discernible in CL-spectra of 
Evate apatite (Figure 13), whereas the $580 \mathrm{~nm}$ emission is obliterated by the $\mathrm{Eu}^{3+}+\mathrm{Dy}^{3+}$ band centered at $575 \mathrm{~nm}$.

Patchy CL-zones with brown (BR) and blue (BL) luminescence show only moderate variations in individual REE's. The BL zone is relatively depleted in La-Nd, but both zones have very similar Eu, Dy, and Sm contents (Figure 9). The corresponding CL-emission spectra (Figure 13) differ in terms of the intensity of $\mathrm{Dy}^{3+}$ emission and the position of the shoulder at $400-450 \mathrm{~nm}$, which could be attributed to $\mathrm{Eu}^{2+}$ [28], crystal defects, and vacancies in the apatite structure [47], or strong activation of $\mathrm{Ce}^{3+}$ at $375 \mathrm{~nm}$. However, due to the $\mathrm{CeO}_{2}$ precipitation, the potential existence of $\mathrm{Eu}^{2+}$ is highly unlikely during the hydrothermal alteration.

\section{Conclusions}

The complex history of the Evate carbonatite deposit is reflected in crystal chemistry, chemical composition, and variability of minor elements in apatite. Geochemical criteria based on trace element concentrations favor the magmatic origin of apatite crystallized during several stages of melt differentiation. Secondary hydrothermal-metasomatic, dissolution-reprecipitation, and deformation processes are reflected in CL textures and particular types of fluid or mineral inclusions. $\mathrm{Dy}^{3+}, \mathrm{Sm}^{3+}$, $\mathrm{Eu}^{3+}$ accompanied by minor $\mathrm{Ce}^{3+}, \mathrm{Tb}^{3+}, \mathrm{Mn}^{2+}$, and $\mathrm{UO}_{2}{ }^{2+}$ have been identified as prominent activators in cathodoluminescce spectra. Barite-celestite and anhydrite inclusions in apatite and the precipitation of cerianite in the mineral assemblage of anhydrite-rich carbonatites indicate strongly oxidizing conditions during the hydrothermal alteration of apatite. U/Th ratios also reflect the partial removal of $\mathrm{U}^{4+}$ from the apatite structure during the interaction with oxidizing aqueous fluids capable of transporting $\mathrm{U}^{6+}$. Despite the extensive metasomatic-hydrothermal alteration, the Evate apatites retained their pristine magmatic trace element signature.

Supplementary Materials: The following are available online at http://www.mdpi.com/2075-163X/10/12/1125/ s1, Table S1: Electron probe micro-analyses and calculated crystallochemical formulas of apatites, Table S2: Laser ablation inductively coupled plasma mass spectrometric analyses of apatites.

Author Contributions: Conceptualization, M.S. and M.H.; methodology, software, data acquisition, and reduction, V.D., M.B.; writing-original draft preparation, M.S., M.H.; writing-review and editing, V.H.; project administration, M.H. and V.H. All authors have read and agreed to the published version of the manuscript.

Funding: This research was funded by the VEGA grant agency, grant numbers 2/0118/16 and 1/0143/18, and by the institutional research fund of the Faculty of Science, Masaryk University (2222/315010).

Acknowledgments: The original draft strongly benefited from constructive comments of three anonymous reviewers. J. Zachariáš (Charles University, Praha) is gratefully thanked for his assistance with CL microscopy and spectroscopy. EPMA masurements could not be done without the expert assistance of P. Konečný, I. Holický, and V. Kollárová. Special thanks go to A. Chakhmouradian for invaluable help in interpreting CL spectra and identification of possible CL activators.

Conflicts of Interest: The authors declare no conflict of interest.

\section{References}

1. Masotti, F.S. Geological characterization of the Evate carbonatite. In Proceedings of the 35th International Geological Congress, Cape Town, South Africa, 27 August-4 September 2016; Abstracts. Curran Associates Inc.: Red Hook, NY, USA. ISBN 978-1-5108-7190-8.

2. Macey, P.H.; Miller, J.A.; Rowe, C.D.; Grantham, G.H.; Siegfried, P.; Armstrong, R.A.; Kemp, J.; Bacalau, J. Geology of the Monapo Klippe, NE Mozambique and its significance for assembly of central Gondwana. Precambr. Res. 2013, 233, 259-281. [CrossRef]

3. Cílek, V. Industrial Minerals of Mozambique; Czech Geological Office: Praha, Czech Republic, 1989; pp. 1-334. ISBN 80-7075-027-8.

4. Hurai, V.; Huraiová, M. Fluid inclusions in apatite indicate low-temperature, metasomatic-infiltration origin of the Evate carbonatite deposit (Mozambique). In Proceedings of the ECROFI XXIII, Leeds, UK, 27-29 June 2015; 2015. Extended Abstract Volume. 
5. Karlsson, J.P. An investigation of the felsic Ramiane Pluton, in the Monapo structure, Northern Mocambique. In Examensarbeten I Geologi Vid Lunds Universitet, Berggrundsgeologi; Lunds Universitet: Lund, Sweden, 2006; Volume 202, pp. 1-37.

6. Ueda, K.; Jacobs, J.; Thomas, R.J.; Kosler, J.; Jourdan, F.; Matola, R. Delamination-induced late-tectonic deformation and high-grade metamorphism of the Proterozoic Nampula Complex, northern Mozambique. Precambr. Res. 2012, 196-197, 275-294. [CrossRef]

7. Simon, A.C.; Knipping, J.; Reich, M.; Barra, F.; Deditius, A.P.; Bilenker, L.; Childress, T. Kiruna-type iron oxide-apatite (IOA) and iron oxide copper-gold (IOCG) deposit form by a combination of igneous and magmatic-hydrothermal processes: Evidence from the Chilean Iron Belt. In Metals, Minerals, and Society; Arribas, A.M., Mauk, J.L., Eds.; SEG Special Publication: Littleton, CO, USA, 2018; Volume 21, pp. 89-114.

8. Nikolenko, A.M.; Redina, A.A.; Doroshkevich, A.G.; Prokopyev, I.R.; Ragozin, A.L.; Vladykin, N.V. The origin of magnetite-apatite rocks of Mushugai-Khudag Complex, South Mongolia: Mineral chemistry and studies of melt and fluid inclusions. Lithos 2018, 320-321, 567-582. [CrossRef]

9. Hurai, V.; Paquette, J.-L.; Huraiová, M.; Slobodník, M.; Hvožd’ara, P.; Siegfried, P.R.; Gajdošová, M.; Milovská, S. New insights into the origin of the Evate apatite-iron oxide-carbonate deposit, Northeastern Mozambique, constrained by mineralogy, textures, thermochronometry, and fluid inclusions. Ore Geol. Rev. 2017, 80, 1072-1091. [CrossRef]

10. Le Bas, M.J. Nephelinites and carbonatites. In Alkaline Igneous Rocks; Fitton, J.G., Upton, B.G.J., Eds.; Geological Society: London, UK, 1987; Volume 30, pp. 85-94.

11. Bailey, D.K. Carbonate melt from the mantle in the volcanoes of south-east Zambia. Nature 1989, 338, 415-418. [CrossRef]

12. Woolley, A.R. Alkaline Rocks and Carbonatites of the World. Part 3: Africa; Geological Society London: Middlesex, UK, 2001; pp. 1-372. ISBN 1-86239-083-5.

13. Siegfried, P.R. The Monapo structure and intrusive complex-An example of large scale alkaline metasomatism in northern Mozambique. In Mineral Deposits: Processes to Processing; Stanley, C.J., Rankin, A.H., Bodnar, R.J., Naden, J., Yardley, B.W.D., Criddle, A.J., Hagni, R.D., Gize, A.P., Pasava, J., Fleet, A.J., et al., Eds.; Balkema: Rotterdam, The Netherlands, 1999; pp. 683-686.

14. Woolley, A.R.; Kjarsgaard, B.A. Carbonatite Occurrences of the World: Map and Database; Open File 5796; Geological Survey Canada; Natural Resources Canada: Ottawa, ON, Canada, 2008; Volume 28.

15. Hurai, V.; Huraiová, M.; Gajdošová, M.; Konečný, P.; Slobodník, M.; Siegfried, P.R. Compositional variations of zirconolite from the Evate apatite deposit (Mozambique) as an indicator of magmatic-hydrothermal conditions during post-orogenic collapse of Gondwana. Mineral. Petrol. 2018, 112, 279-296. [CrossRef]

16. Stoppa, F.; Liu, Y. Chemical composition and petrogenetic implications of apatites from some ultra-alkaline Italian rocks. Eur. J. Mineral. 1995, 7, 391-402. [CrossRef]

17. Hughes, J.M.; Cameron, M.; Crowley, K.D. Ordering of divalent cations in the apatite structure: Solid solution in the $\mathrm{Ca}_{5}\left(\mathrm{PO}_{4}\right)_{3} \mathrm{X}(\mathrm{X}=\mathrm{F}, \mathrm{OH}, \mathrm{Cl})$ system. Am. Mineral. 1991, 75, 295-304.

18. Rakovan, J.; Reeder, R.J. Intracrystalline rare earth element distributions in apatite: Surface structural influences on inroporation during growth. Geochim. Cosmochim. Acta 1996, 60, 4435-4445. [CrossRef]

19. Pan, Y.; Fleet, M.E. Composition of the apatite-group minerals: Substitution mechanism and controlling factors. Rev. Mineral. Geochem. 2002, 48, 13-50. [CrossRef]

20. Gittins, J. The origin and evolution of carbonatite magmas. In Carbonatites: Genesis and Evolution; Bell, K., Ed.; Unwin Hyman: London, UK, 1989; pp. 580-590.

21. Seifert, W.; Kampf, H.; Wasternack, J. Compositional variation in apatite, phlogopite and other accessory minerals of the ultramafic Delitzsch complex, Germany: Implication for cooling history of carbonatites. Lithos 2000, 53, 81-100. [CrossRef]

22. Piccoli, P.M.; Candela, P.A. Apatite in igneous systems. Rev. Mineral. Geochem. 2002, 48, 255-292. [CrossRef]

23. Webster, J.D.; Piccoli, P.M. Magmatic apatite: A powerful, yet deceptive, mineral. Elements 2015, 11, 177-182. [CrossRef]

24. Bühn, B.; Wall, F.; Le Bas, M.J. Rare-earth element systematics of carbonatitic fluorapatites and their significance for carbonatite magma evolution. Contrib. Mineral. Petrol. 2001, 141, 572-591. [CrossRef]

25. Teiber, H.; Marks, M.A.W.; Arzamastsev, A.A.; Wenzel, T.; Markl, G. Compositional variation in apatite from various host rocks: Clues with regards to source composition and crystallization conditions. Neues Jrb. Mineral. 2015, 192, 151-167. [CrossRef] 
26. Belousova, E.A.; Griffin, W.L.; O’Reilly, S.Z.; Fisher, N.I. Apatite as an indicator mineral for exploration: Trace element comopositions and their relationship to host rock type. J. Geochem. Explor. 2002, 76, 45-69. [CrossRef]

27. Mao, M.; Rukhlov, A.S.; Rowins, S.M.; Spence, J.; Coogan, L.A. Apatite trace element compositions: A robust new tool for mineral exploration. Econ. Geol. 2016, 111, 1187-1222. [CrossRef]

28. Chakhmouradian, A.R.; Reguir, E.P.; Zaitsev, A.N.; Couëslan, C.; Xu, C.; Kynický, J.; Mumin, A.H.; Yang, P. Apatite in carbonatitic rocks: Compositional variation, zoning, element partitioning and petrogenetic significance. Lithos 2017, 274-275, 188-213. [CrossRef]

29. Harlov, D.E. Apatite: A fingerprint for metasomatic processes. Elements 2015, 11, 171-176. [CrossRef]

30. Krneta, S.; Ciobanu, C.L.; Cook, N.J.; Ehrig, K.J. Numerical modeling of REE fractionation patterns in fluorapatite from the Olympic Dam deposit (south Australia). Minerals 2018, 8, 342. [CrossRef]

31. Pinna, P.; Jourde, G.; Calvez, J.Y.; Mroz, J.P.; Marques, J.M. The Mozambique Belt in northern Mozambique: Neoproterozoic (1100-850 Ma) crustal growth and tectogenesis, and superimposed Pan-African (800-550 Ma) tectonism. Precambr. Res. 1993, 62, 1-59. [CrossRef]

32. Grantham, G.H.; Macey, P.H.; Ingram, B.A.; Roberts, M.P.; Armstrong, R.A.; Hokada, T.; Shiraishi, K.; Jackson, C.; Bisnath, A.; Manhiça, V. Terrane correlation between Antarctica, Mozambique and Sri Lanka: Comparison of geochronology, lithology, structure and metamorphism and possible implications for the geology of southern Africa and Antarctica. In Geodynamic Evolution of East Antarctica: A Key to the East-West Gondwana Connection; Satish-Kumar, M., Motoyoshi, Y., Osanai, Y., Hiroi, Y., Siraishi, K., Eds.; Geological Society: London, UK, 2008; Volume 308, pp. 91-119.

33. Grantham, G.H.; Macey, P.H.; Horie, K.; Kawakami, T.; Ishikawa, M.; Satish-Kumar, M.; Tsuchiya, N.; Graser, P.; Azevedo, S. Comparison of the metamorphic history of the Monapo complex, northern Mozambique and Balchenfjella and Austhameren areas, Sor Rondane, Antarctica: Implications for the Kuunga orogeny and the amalgamation of N. and S. Gondwana. Precambr. Res. 2013, 234, 85-135. [CrossRef]

34. Viola, G.; Henderson, I.H.C.; Bingen, B.; Thomas, R.J.; Smethurst, M.A.; de Azavedo, S. Growth and collapse of a deeply eroded orogen: Insights from structural and geochronological constraints on the Pan-African evolution of NE Mozambique. Tectonics 2008, 27, TC50009. [CrossRef]

35. Bingen, B.; Jacobs, J.; Viola, G.; Henderson, I.H.C.; Skar, Ø.; Boyd, R.; Thomas, R.J.; Solli, A.; Key, R.M.; Daudi, E.X.F. Geochronology of the Precambrian crust in the Mozambique belt in NE Mozambique, and implications for Gondwana assembly. Precambr. Res. 2009, 170, 231-255. [CrossRef]

36. Macey, P.H.; Thomas, R.J.; Grantham, G.H.; Ingram, B.A.; Jacobs, J.; Armstrong, R.A.; Roberts, M.P.; Bingen, B.; Hollick, L.; De Kock, G.S.; et al. Mesoproterozoic geology of the Nampula Block, northern Mozambique: Tracing fragments of Mesoproterozoic crust in the heart of Gondwana. Precambr. Res. 2010, 182, 124-148. [CrossRef]

37. Hurai, V.; Blažeková, M.; Huraiová, M.; Siegfried, P.R.; Slobodník, M.; Konečný, P. Thermobarometric and geochronologic constraints on the emplacement of the Neoproterozoic Evate carbonatite during exhumation of the Monapo granulite complex. Lithos 2020, in press. [CrossRef]

38. Callaghan, C.C. Mineral resource based growth pole industrialisation-Phosphate Report. In Regional Integration Research Network; TMSA: Burnside, QLD, Australia, 2013; pp. 1-64.

39. Jamal, D.L. Crustal Studies across Selected Geotransects in NE Mozambique: Differentiating between Mozambiquian ( Kibaran) and Pan-African Events, with Implications for Gondwana Studies. Ph.D. Thesis, University of Cape Town, Rondebosch, South Africa, 2005.

40. Engvik, A.K.; Bingen, B. Granulite-facies metamorphism of the Palaeoproterozoic-Early Palaeozoic gneiss domains of NE Mozambique, East African Orogen. Geol. Mag. 2017, 154, 491-515. [CrossRef]

41. Fritz, H.; Abdelsalam, M.; Ali, K.A.; Bingen, B.; Collins, A.S.; Fowler, A.R.; Ghebreab, W.; Hauzenberger, C.A.; Johnson, P.R.; Kusky, T.M.; et al. Orogen styles in the East African orogen: A review of the Neoproterozoic to Cambrian tectonic evolution. J. Afr. Earth Sci. 2013, 86, 65-106. [CrossRef]

42. Merlet, C. Accurate description of surface ionization in electron probe microanalysis: An improved formulation. X-ray Spectrom. 1992, 21, 229-238. [CrossRef]

43. Pasero, M.; Kampf, A.R.; Ferraris, C.; Pekov, I.V.; Rakovan, J.; White, T.J. Nomenclature of the apatite supergroup minerals. Eur. J. Mineral. 2010, 22, 163-179. [CrossRef]

44. Comodi, P.; Liu, Y.; Stoppa, F.; Woolley, A.R. A multi-method analysis of Si-, S- and REE-rich apatite from a new find of kalsilite-bearing leucitite (Abruzzi, Italy). Mineral. Mag. 1999, 63, 661-672. [CrossRef] 
45. Anders, E.; Grevesse, N. Abundances of the elements: Meteoritic and solar. Geochim. Cosmochim. Acta 1989, 53, 197-214. [CrossRef]

46. Decrée, S.; Boulvais, P.; Tack, L.; André, L.; Baele, J.-M. Fluorapatite in carbonatite-related phosphate deposits: The case of the Matongo carbonatite (Burundi). Mineral. Dep. 2016, 51, 453-466. [CrossRef]

47. MacRae, C.M.; Wilson, N.C.; Torpy, A.; Davidson, C.J. Hyperspectral cathodoluminescence imaging and analysis extending from ultraviolet to near infrared. Microsc. Microanal. 2012, 18, 1239-1245. [CrossRef] [PubMed]

48. Barbarand, J.; Pagel, M. Cathodoluminescence study of apatite crystals. Am. Mineral. 2001, 86, 473-484. [CrossRef]

49. Roedder, P.L.; MacArthur, D.; Ma, X.-A.; Palmer, G.R.; Mariano, A.N. Cathodoluminescence and microprobe study of rare-earth elements in apatite. Am. Mineral. 1987, 72, 801-811.

50. Arzamastsev, A.; Arzamastseva, L.; Bea, F.; Montero, P. Trace elements in minerals as indicators of the evolution of alkaline ultrabasic dike series: LA-ICP-MS data for the magmatic provinces of northeastern Fennoscandia and Germany. Petrology 2009, 17, 46-72. [CrossRef]

51. Kogarko, L. Chemical composition and petrogenetic implications of apatite in the Khibiny apatite-nepheline deposits (Kola Peninsula). Minerals 2018, 8, 532. [CrossRef]

52. Bonyadi, Z.; Davidson, G.J.; Mehrabi, B.; Meffre, S.; Ghazban, F. Significance of apatite REE depletion and monazite inclusions in the brecciated Se-Chahun iron oxide-apatite deposit, Bafq district, Iran: Insights from paragenesis and geochemistry. Chem. Geol. 2011, 281, 253-269. [CrossRef]

53. Cao, M.; Li, G.; Qin, K.; Seitmuratova, E.Y.; Liu, Y. Major and trace element characteristics of apatites in granitoids from central Kazakhstan: Implications for petrogenesis and mineralization. Res. Geol. 2011, 62, 63-83. [CrossRef]

54. Chen, W.T.; Zhou, M.F.; Zhao, T.P. Differentiation of nelsonitic magmas in the formation of the $\sim 1.94 \mathrm{Ga}$ Damiao Fe-Ti-P ore deposit, North China. Contrib. Mineral. Petrol. 2013, 165, 1341-1362. [CrossRef]

55. Chu, M.F.; Wang, K.L.; Griffin, W.L.; Chung, S.L.; O’Reilly, S.Y.; Pearson, N.J.; Iizuka, Y. Apatite composition: Tracing petrogenesis processes in Transhimalayan granitoids. J. Petrol. 2009, 50, 1829-1855. [CrossRef]

56. Frietsch, R.; Perdahl, J.-A. Rare earth elements in apatite and magnetite in Kiruna-type iron ores and some other iron ore types. Ore Geol. Rev. 1995, 9, 489-510. [CrossRef]

57. Ziemann, M.A.; Förster, H.J.; Harlov, D.; Frei, D. Origin of fluorapatite-monazite assemblages in metamorphosed, sillimanite-bearing pegmatoid, Reibolt Hills, East Antarctica. Eur. J. Mineral. 2005, 17, 567-579. [CrossRef]

58. Broom-Fendley, S.; Styles, M.T.; Appleton, J.D.; Gunn, G.; Wall, F. Evidence for dissolution-reprecipitation of apatite and preferential LREE mobility in carbonatite derived late-stage hydrothermal processes. Am. Mineral. 2016, 101, 596-611. [CrossRef]

59. Ying, J.; Zhou, X.; Zhang, H. Geochemical and isotopic investigation of the Laiwu-Zibo carbonatites from western Shandong Province, China, and implications for their petrogenesis and enriched mantle source. Lithos 2004, 75, 413-426. [CrossRef]

60. Zaitsev, A.N.; Chakhmouradian, A.R. Calcite-amphibole-clinopyroxene rock from the Afrikanda complex, Kola Peninsula. Russia: Mineralogy and a possible link to carbonatites. III. Silicate minerals. Can. Mineral. 2002, 43, 1347-1374. [CrossRef]

61. Chakhmouradian, A.R.; Reguir, E.P.; Kressall, R.D.; Crozier, J.; Pisiak, L.; Sidhu, R.; Yang, P. Carbonatite-hosted niobium deposit at Aley, northern British Columbia (Canada): Mineralogy, geochemistry and petrogenesis. Ore Geol. Rev. 2015, 64, 642-666. [CrossRef]

62. Mercer, C.N.; Watts, K.E.; Gross, J. Apatite trace element geochemistry and cathodoluminescent textures-A comparison between regional magmatism and the Pea Ridge IOAREE and Boss IOCG deposits, southeastern Missouri iron metallogenic province, USA. Ore Geol. Rev. 2020, 116, 103129. [CrossRef]

63. Decrée, S.; Cawthorn, G.; Deloule, E.; Mercadier, J.; Frimme, H.; Baele, J.-M. Unravelling the processes controlling apatite formation in the Phalaborwa Complex (South Africa) based on combined cathodoluminescence, LA-ICPMS and in-situ $\mathrm{O}$ and Sr isotope analyses. Contrib. Mineral. Petrol. 2020, 175, 34. [CrossRef]

64. Mitchell, R.H. Cathodoluminescence of apatite. In Cathodoluminescence and Its Application to Geoscience; Coulson, I.M., Ed.; Mineral Association of Canada Short Course Series; Mineralogical Association of Canada: Quebec City, QC, Canada, 2014; Volume 45, pp. 143-168. 
65. Waychunas, G.A. Apatite luminescence. Rev. Mineral. Geochem. 2002, 48, 701-742. [CrossRef]

66. Kempe, U.; Götze, J. Cathodoluminescence (CL) behavior and crystal chemistry of apatites from rare-metal deposits. Mineral. Mag. 2002, 66, 151-172. [CrossRef]

67. deNeufville, J.P.; Kasdan, A.; Chimenti, R.J.L. Selective detection of uranium by laser-induced fluorescence: A potential remote-sensing technique. 1: Optical characteristics of uranyl geologic targets. Appl. Optics 1981, 20, 1279-1296. [CrossRef] [PubMed]

Publisher's Note: MDPI stays neutral with regard to jurisdictional claims in published maps and institutional affiliations.

(C) 2020 by the authors. Licensee MDPI, Basel, Switzerland. This article is an open access article distributed under the terms and conditions of the Creative Commons Attribution (CC BY) license (http://creativecommons.org/licenses/by/4.0/). 